\title{
Factors influencing the stable carbon isotopic composition of suspended and sinking organic matter in the coastal Antarctic sea ice environment
}

\author{
S. F. Henley ${ }^{1}$, A. L. Annett ${ }^{1}$, R. S. Ganeshram ${ }^{1}$, D. S. Carson ${ }^{1}$, K. Weston ${ }^{2}$, X. Crosta ${ }^{3}$, A. Tait ${ }^{4}$, J. Dougans ${ }^{4}$, \\ A. E. Fallick ${ }^{4}$, and A. Clarke ${ }^{5}$ \\ ${ }^{1}$ School of GeoSciences, The University of Edinburgh, West Mains Road, Edinburgh EH9 3JW, UK \\ ${ }^{2}$ Laboratory of Global Marine and Atmospheric Chemistry, School of Environmental Sciences, University of East Anglia, \\ Norwich, NR4 7TJ, UK \\ ${ }^{3}$ UMR-CNRS 5805 EPOC, Universite Bordeaux 1, Av. Des Facultes, 33405 Talence, Cedex, France \\ ${ }^{4}$ Scottish Universities Environmental Research Centre, Scottish Enterprise Technology Park, Rankine Avenue, \\ East Kilbride, Glasgow, G75 0QF, UK \\ ${ }^{5}$ British Antarctic Survey, High Cross, Madingley Road, Cambridge, CB3 OET, UK
}

Correspondence to: S. F. Henley (s.f.henley@sms.ed.ac.uk)

Received: 7 October 2011 - Published in Biogeosciences Discuss.: 16 November 2011

Revised: 7 March 2012 - Accepted: 8 March 2012 - Published: 27 March 2012

\begin{abstract}
A high resolution time-series analysis of stable carbon isotopic signatures in particulate organic carbon $\left(\delta^{13} \mathrm{C}_{\mathrm{POC}}\right)$ and associated biogeochemical parameters in sea ice and surface waters provides an insight into the factors affecting $\delta^{13} \mathrm{C}_{\mathrm{POC}}$ in the coastal western Antarctic Peninsula sea ice environment. The study covers two austral summer seasons in Ryder Bay, northern Marguerite Bay between 2004 and 2006. A shift in diatom species composition during the 2005/06 summer bloom to near-complete biomass dominance of Proboscia inermis is strongly correlated with a large $\sim 10 \%$ negative isotopic shift in $\delta^{13} \mathrm{C}_{\mathrm{POC}}$ that cannot be explained by a concurrent change in concentration or isotopic signature of $\mathrm{CO}_{2}$. We hypothesise that the $\delta^{13} \mathrm{C}_{\mathrm{POC}}$ shift may be driven by the contrasting biochemical mechanisms and utilisation of carbon-concentrating mechanisms (CCMs) in different diatom species. Specifically, very low $\delta^{13} \mathrm{C}_{\mathrm{POC}}$ in $P$. inermis may be caused by the lack of a CCM, whilst some diatom species abundant at times of higher $\delta^{13} \mathrm{C}_{\mathrm{POC}}$ may employ CCMs. These short-lived yet pronounced negative $\delta^{13} \mathrm{C}_{\mathrm{POC}}$ excursions drive a $4 \%$ decrease in the seasonal average $\delta^{13} \mathrm{C}_{\mathrm{POC}}$ signal, which is transferred to sediment traps and core-top sediments and consequently has the potential for preservation in the sedimentary record. This $4 \%$ difference between seasons of contrasting sea ice conditions and upper water column stratification matches the full amplitude of glacial-interglacial Southern Ocean $\delta^{13} \mathrm{C}_{\mathrm{POC}}$
\end{abstract}

variability and, as such, we invoke phytoplankton species changes as a potentially important factor influencing sedimentary $\delta^{13} \mathrm{C}_{\mathrm{POC}}$. We also find significantly higher $\delta^{13} \mathrm{C}_{\mathrm{POC}}$ in sea ice than surface waters, consistent with autotrophic carbon fixation in a semi-closed environment and possible contributions from post-production degradation, biological utilisation of $\mathrm{HCO}_{3}^{-}$and production of exopolymeric substances. This study demonstrates the importance of surface water diatom speciation effects and isotopically heavy sea ice-derived material for $\delta^{13} \mathrm{C}_{\mathrm{POC}}$ in Antarctic coastal environments and underlying sediments, with consequences for the utility of diatom-based $\delta^{13} \mathrm{C}_{\mathrm{POC}}$ in the sedimentary record.

\section{Introduction}

During photosynthetic uptake of aqueous carbon dioxide, marine phytoplankton preferentially assimilate the lighter isotope, carbon-12, thus increasing the stable carbon isotopic signature, $\delta^{13} \mathrm{C}$, of the residual pool of dissolved inorganic carbon (DIC). As such, marine algae always display lower $\delta^{13} \mathrm{C}_{\mathrm{POC}}$ than the inorganic carbon source they assimilate (Hayes, 1993). Several studies have demonstrated that on large oceanic scales, $\delta^{13} \mathrm{C}$ of the product organic carbon $\left(\delta^{13} \mathrm{C}_{\mathrm{POC}}\right)$ is inversely correlated with the concentration of 
dissolved molecular carbon dioxide $\left(\left[\mathrm{CO}_{2(a q)}\right]\right)$ in surface waters (Rau et al., 1989, 1991). This inverse relationship has been exploited to use $\delta^{13} \mathrm{C}_{\mathrm{POC}}$ in marine sediment cores as a proxy to reconstruct surface water $\left[\mathrm{CO}_{2(a q)}\right]$ and atmospheric $p \mathrm{CO}_{2}$ in the past (Jasper and Hayes, 1990; Freeman and Hayes, 1992; Bentaleb and Fontugne, 1998).

However, several studies have demonstrated that this relationship cannot be applied universally and in high-southern latitudes particularly, the anti-correlation between $\delta^{13} \mathrm{C}_{\mathrm{POC}}$ and $\left[\mathrm{CO}_{2(a q)}\right]$ can be decoupled by physical and biological factors. Amongst these factors are phytoplankton growth rate and its regulation by temperature and light levels (O'Leary et al., 2001), cell size and shape (Popp et al., 1998; Burkhardt et al., 1999; Trull and Armand, 2001) and non-diffusive carbon uptake through carbon concentration mechanisms (Rau, 2001; Cassar et al., 2004).

Paleoceanographic studies of the Southern Ocean have observed that the $\delta^{13} \mathrm{C}$ of diatom-bound organic matter was depleted in ${ }^{13} \mathrm{C}$ during glacial times relative to interglacials and the Holocene (Singer and Shemesh, 1995; Rosenthal et al., 2000; Crosta and Shemesh, 2002; Schneider-Mor et al., 2005). However, ice core records show that glacial $p \mathrm{CO}_{2}$ was lower than during interglacials (Berner et al., 1980; Barnola et al., 1987; Masson-Delmotte et al., 2010), which would be expected to drive $\delta^{13} \mathrm{C}_{\mathrm{POC}}$ more positive. Definitive explanations for low glacial $\delta^{13} \mathrm{C}_{\mathrm{POC}}$ remain unclear but potential contributing factors include lower algal growth rates during glacial periods (Rosenthal et al., 2000), sea ice-triggered increase in $\left[\mathrm{CO}_{2(a q)}\right]$ (Crosta and Shemesh, 2002) and the effects of changes in diatom abundance or species composition (Crosta et al., 2005). Documenting the processes that decouple carbon isotopes from the classic $\delta^{13} \mathrm{C}_{\mathrm{POC}}$ versus $p \mathrm{CO}_{2}$ relationship used for paleo- $\mathrm{CO}_{2}$ reconstructions is important in understanding the role of the Southern Ocean in glacial-interglacial climate change. This study provides a detailed high-resolution time-series analysis of carbon isotopes and associated biogeochemical parameters in surface waters, sea ice, sediment traps and core-top sediments in order to elucidate the key factors influencing surface and sinking $\delta^{13} \mathrm{C}_{\mathrm{POC}}$ in the Antarctic sea ice zone on a seasonal timescale, as well as their potential for preservation in marine sediments.

\section{Materials and methods}

\subsection{Study area}

This study was conducted over two growing seasons and the intervening winter of full sea ice cover between 2004 and 2006 in Ryder Bay and Marguerite Bay, located south of Adelaide Island, west of the Antarctic Peninsula mainland (Fig. 1). Ryder Bay is a coastal, seasonally sea ice-covered Southern Ocean environment in which diatoms dominate the summer assemblages, with biomass of other phytoplankton such as prymnesiophytes and cryptophytes more than an order of magnitude lower (Garibotti et al., 2005). Ryder Bay adjoins Marguerite Bay and the principal study site is the Rothera Oceanographic and Biological Time-Series (RaTS) site at $67^{\circ} 34.02^{\prime} \mathrm{S}, 68^{\circ} 14.02^{\prime} \mathrm{W}$ (Clarke et al., 2008), situated in open water of depth $520 \mathrm{~m}$. If access to the main RaTS site is prevented by weather or ice conditions, a secondary station at $67^{\circ} 34.85^{\prime} \mathrm{S}, 68^{\circ} 09.34^{\prime} \mathrm{W}$ of water depth $\sim 400 \mathrm{~m}$ is used as an alternative site also representative of prevailing oceanographic conditions in Ryder Bay. The Marguerite Bay site is located at $67^{\circ} 55.39^{\prime} \mathrm{S}, 68^{\circ} 24.15^{\prime} \mathrm{W}$ in open water of depth $840 \mathrm{~m}$.

\subsection{Sea ice sampling}

Sea ice brine was sampled according to sea ice availability at three locations: the RaTS site, Hangar Cove and Lagoon Island (Fig. 1). Fifteen samples were taken over the course of the study: five Lagoon Island land-fast ice samples taken in December 2004, two winter sea ice samples taken at the RaTS site in September and October 2005 and eight early spring samples from Hangar Cove in November and December 2005 .

Sea ice brine was sampled using a sack hole drilling method, with samples for the stable carbon isotopic composition of $\mathrm{CO}_{2}\left(\delta^{13} \mathrm{C}_{\mathrm{CO}_{2}}\right)$ and $\left[\mathrm{CO}_{2(a q)}\right]$ taken first to minimise atmospheric contamination. Samples for $\delta^{13} \mathrm{C}_{\mathrm{CO}_{2}}$ were taken using a $50 \mathrm{ml}$ syringe and gently injected into a $12 \mathrm{ml}$ glass exetainer vial preloaded with $50 \mu \mathrm{L}$ of $35 \mathrm{gL}^{-1}$ copper (II) sulphate to suppress bacterial activity (Winslow et al., 2001).

Samples for alkalinity and $\mathrm{pH}$, for $\left[\mathrm{CO}_{2(a q)}\right]$ determination, were taken by immersing a $250 \mathrm{ml}$ glass biological oxygen demand (BOD) bottle in the sack hole, ensuring no air bubbles were included and sealing the bottle with a ground glass stopper. On return to the laboratory, samples were stored, unfiltered, in the dark overnight to allow them to reach room temperature and thus maintain a steady temperature throughout subsequent analysis on the following day.

For particulate organic carbon measurements, sea ice brine samples were filtered through muffle-furnaced $\left(400^{\circ} \mathrm{C}\right.$ for $4 \mathrm{~h}) 47 \mathrm{~mm}$ diameter $\mathrm{GF} / \mathrm{F}$ filters, of pore size $\sim 0.7 \mu \mathrm{m}$, within two hours of collection. The filters were then dried at $50^{\circ} \mathrm{C}$ overnight, and stored frozen until analysis. For diatom census counts, sea ice brine was filtered through $37 \mathrm{~mm}$ diameter polycarbonate filters, of pore size $0.45 \mu \mathrm{m}$. Filters were dried overnight at $50^{\circ} \mathrm{C}$ and stored in clean plastic Petri-slides until analysis.

\subsection{Surface water sampling}

A high resolution time series of surface water samples was taken in Ryder Bay, at the RaTS site during the austral spring and summer of 2004/05 and 2005/06. Low resolution time series sampling was conducted during winter 2005. 


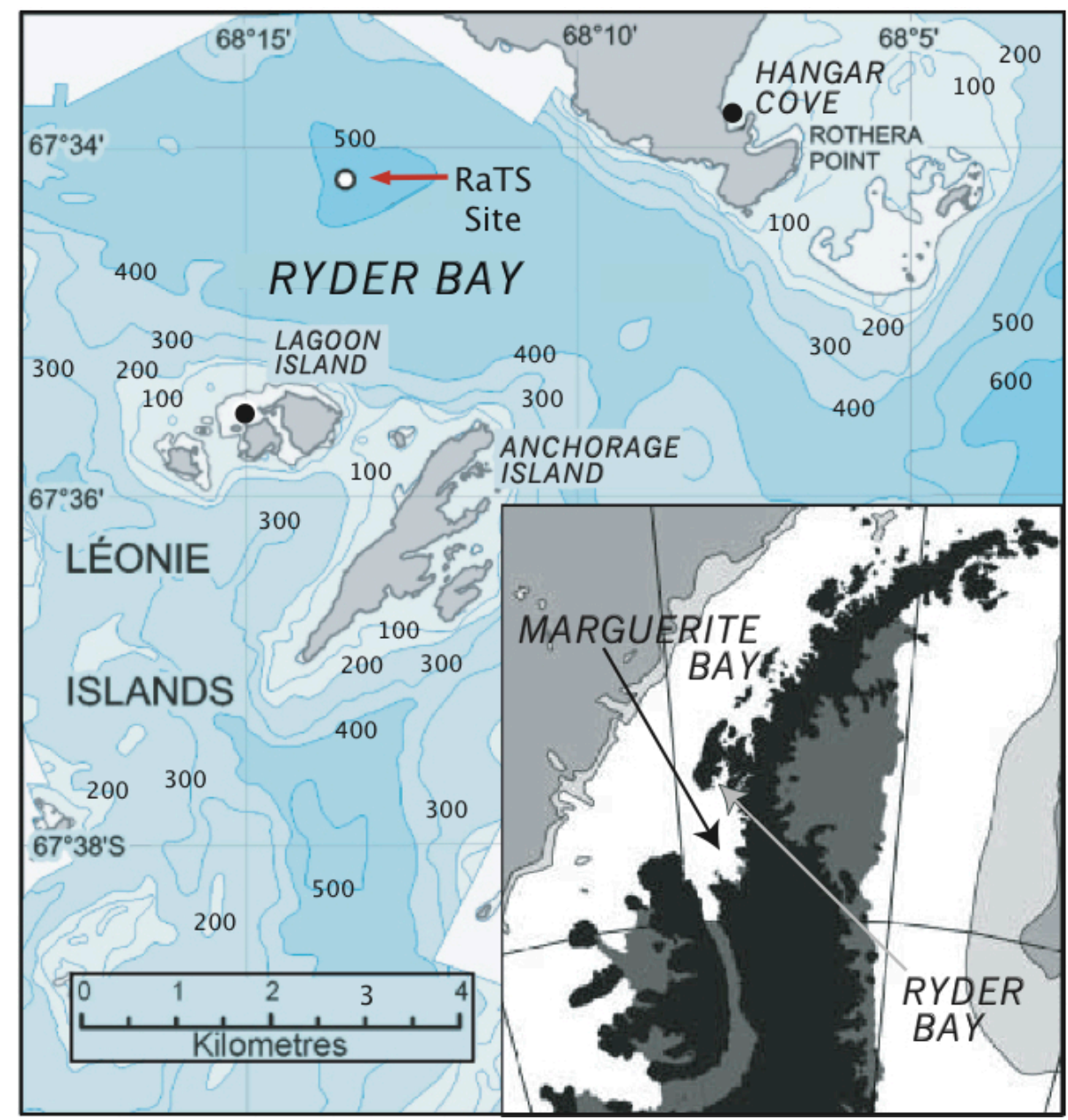

Fig. 1. Map of Ryder Bay showing the RaTS site, Hangar Cove and Lagoon Island sampling stations. Map courtesy of the British Antarctic Survey. Inset shows position of Ryder Bay on the western Antarctic Peninsula. After Clarke et al. (2007, 2008).

A normal sampling event consisted of collection of seawater samples from $15 \mathrm{~m}$ water depth, the average depth of the chlorophyll maximum in Ryder Bay since sampling began in 1997 (Clarke et al., 2008). Samples were taken for determination of chlorophyll $a,\left[\mathrm{CO}_{2(a q)}\right], \delta^{13} \mathrm{C}_{\mathrm{CO}_{2}}$, suspended POC, $\delta^{13} \mathrm{C}_{\mathrm{POC}}$ and diatom assemblages and measurements were taken for temperature and salinity using a YSI-500 multi-parameter meter. Each sampling event was accompanied by a full-depth Conductivity Temperature Depth (CTD) cast to monitor changes in mixed layer depth.

CTD casts were taken to $500 \mathrm{~m}$ depth using a Sea Bird 19+ CTD module with a WetLabs in-line fluorometer and LiCor PAR sensor. For measurement of temperature at the $15 \mathrm{~m}$ sampling depth, a Sensoren Instrumente Systeme GmbH reversible thermometer was lowered to $15 \mathrm{~m}$ and allowed to equilibrate for two minutes before a brass messenger was sent down to initiate temperature recording.
Surface water samples were taken using a $5 \mathrm{~L}$ Niskin bottle for chlorophyll $a, \delta^{13} \mathrm{C}_{\mathrm{CO}_{2}}$ and $\left[\mathrm{CO}_{2(a q)}\right]$ measurements. For $\delta^{13} \mathrm{C}_{\mathrm{CO}_{2}}$, water was drawn from the Niskin bottle using a $50 \mathrm{ml}$ syringe and gently injected into a $12 \mathrm{ml}$ glass exetainer vial preloaded with $50 \mu \mathrm{L}$ of $35 \mathrm{gL}^{-1}$ copper sulphate to suppress bacterial activity (Winslow et al., 2001). Samples for alkalinity and $\mathrm{pH}$, for $\left[\mathrm{CO}_{2(a q)}\right]$ determination, were taken from the Niskin straight into a $250 \mathrm{ml}$ glass BOD bottle, which was immediately sealed with a ground glass stopper whilst overflowing and ensuring that no air bubbles were present. These samples were left overnight, as for the equivalent sea ice samples. Chlorophyll samples were collected and treated as per Clarke et al. (2008). Particulate samples were retrieved using a $12 \mathrm{~V}$ whale pump and $15 \mathrm{~m}$ of silicone tubing weighted down at the end. Water from $15 \mathrm{~m}$ was pumped into 10 L HDPE carboys for transfer back to the laboratory. Surface water samples were prepared for particulate organic carbon measurements and diatom census counts in the same way as was sea ice brine. 


\subsection{Sediment trap and surface sediment sampling}

Two sediment trap mooring arrays were deployed to catch sinking particles for $\delta^{13} \mathrm{C}_{\mathrm{POC}}$ analysis and flux calculations, concurrent with the time series water sampling programme; one at the RaTS site and the other at the deeper Marguerite Bay site.

Each mooring consisted of two time-series sediment traps, at $200 \mathrm{~m}$ and $512 \mathrm{~m}$ for the RaTS mooring and $123 \mathrm{~m}$ and $745 \mathrm{~m}$ for the Marguerite Bay mooring. Each sediment trap consisted of 21 rotating cups programmed to rotate at predefined intervals. Cup turnover times were shorter giving higher resolution during periods of potential sea ice melt and the spring bloom, whilst lower resolution cup rotation was used during the low flux winter periods.

Both sediment trap mooring arrays were deployed from late-January 2005 to mid-February 2006. Upon recovery, all sediment trap bottles were removed and replaced, and the moorings redeployed.

Prior to deployment, each cup was filled with filtered seawater spiked with an extra $5 \% \mathrm{NaCl}$ in order to increase its density and prevent mixing with the overlying seawater. Finally, cups were spiked with formaldehyde to give an overall concentration of $2 \%(\mathrm{v} / \mathrm{v})$ to prevent bioturbation, by killing swimmers and stopping biological activity. Formaldehydepreservation of sediment trap material for $\delta^{13} \mathrm{C}_{\mathrm{POC}}$ analysis is widely used (Thunell et al., 2000; Struck et al., 2004; Mincks et al., 2008) and is deemed appropriate for the purposes of this study since formaldehyde preservative does not add sufficient organic carbon to sediment trap material to alter $\delta^{13} \mathrm{C}_{\mathrm{POC}}$ (Altabet, 2001).

Box core samples were taken at the RaTS site and the Marguerite Bay site in January 2005 and December 2006 aboard R.R.S. James Clark Ross. In each case, the box core was taken and then four sub-cores of approximately $30 \mathrm{~cm}$ were taken by pushing plastic sleeves through the box core. Coretop samples were collected from the top two $0.5 \mathrm{~cm}$ intervals from each sub-core.

\subsection{Surface water and sea ice $\left[\mathrm{CO}_{2(a q)}\right]$ and $\delta{ }^{13} \mathrm{C}_{\mathrm{CO}_{2}}$ determination}

$\left[\mathrm{CO}_{2(a q)}\right]$ was determined using measurements of salinity and temperature, detailed above, with $\mathrm{pH}$ and alkalinity, both determined on the day following sampling. $\mathrm{pH}$ measurements were performed using a bench-top $\mathrm{pH}$ meter calibrated to buffer solutions of $\mathrm{pH} 4.01,7.00$ and 10.01. Maximum error on triplicate $\mathrm{pH}$ measurements across all samples was \pm 0.02 . Alkalinity was determined by titration with 0.05 $\mathrm{M} \mathrm{HCl}$ and the Gran plot method (Almgren et al., 1983). $\left[\mathrm{CO}_{2(a q)}\right]$ was calculated using constants from Dickson and Millero (1987), Hannson (1973) and Mehrbach et al. (1973) using the CO2SYS programme (Lewis and Wallace, 1998). Maximum error on $\left[\mathrm{CO}_{2(a q)}\right]$ calculations, taking into account the maximum error on all input parameters, is $11.0 \%$. $\delta^{13} \mathrm{C}_{\text {DIC }}$ analysis was conducted by GC-IRMS using a method similar to Assayag et al. (2006). The $12 \mathrm{ml}$ glass exetainer vial containing $12 \mathrm{ml}$ of seawater sample spiked with $\mathrm{CuSO}_{4} .5 \mathrm{H}_{2} \mathrm{O}$ was split into two samples by inserting a closed syringe through the septum of the vial and injecting $6 \mathrm{ml}$ of Helium gas into the sample vial using a separate needle and syringe. The $6 \mathrm{ml}$ of sample forced into the closed syringe by the He injection was then injected into a clean $12 \mathrm{ml}$ exetainer vial that had been under vacuum for $30 \mathrm{~min}$. Each sample vial was then injected with $0.6 \mathrm{ml}$ of concentrated $\mathrm{H}_{3} \mathrm{PO}_{4}$ in order to convert the DIC into aqueous and gaseous $\mathrm{CO}_{2}$ for analysis. Three sets of isotopic standards were prepared (MAB2, $\mathrm{CaCO}_{3}$ and $\left.\mathrm{NaHCO}_{3}\right)$ using a range of final DIC concentrations. The standards were weighed into $12 \mathrm{ml}$ glass exetainer vials and then placed on a vacuum to remove all gases. $6 \mathrm{ml}$ of $10 \% \mathrm{H}_{3} \mathrm{PO}_{4}$ was then injected into each standard vial to reproduce the same conditions as in the sample vials. $\delta^{13} \mathrm{C}_{\mathrm{DIC}}$ was analysed using a custom-built GC-IRMS system, from which raw $\delta^{13} \mathrm{C}$ values were corrected using the isotopic standards. Precision of $\delta^{13} \mathrm{C}_{\text {DIC }}$ values was generally better than $0.2 \%$ o. $\delta^{13} \mathrm{C}_{\mathrm{CO}_{2}}$ was determined from $\delta^{13} \mathrm{C}_{\mathrm{DIC}}$ and absolute temperature $\left(T_{K}\right.$ in Kelvin) using Eq. (1) from Rau et al. (1996):

$\delta^{13} C_{\mathrm{CO}_{2}}=\delta^{13} C_{\mathrm{DIC}}+23.644-9701.5 / T_{K}$

\subsection{POC, PN and $\delta^{13} C_{P O C}$ analysis}

Bulk POC, particulate nitrogen (PN) and $\delta^{13} \mathrm{C}_{\mathrm{POC}}$ analyses were conducted using a method similar to Lourey et al. (2004). Prior to analysis, the filters were decarbonated by wetting with Milli-Q water and fuming with $\mathrm{HCl}$ for $48 \mathrm{~h}$ and then drying at $50^{\circ} \mathrm{C}$. Filters were cut in half and analysed for elemental POC, PN and $\delta^{13} \mathrm{C}_{\mathrm{POC}}$ using a Carlo Erba NA 2500 elemental analyser in-line with a VG PRISM III isotope ratio mass spectrometer. The two halves were analysed separately and then data were summed, to achieve final representative values for the whole filters. All $\delta^{13} \mathrm{C}$ data are presented in the delta per mil notation versus V-PDB (\%o VPDB).

\subsection{Diatom species counts}

Diatom assemblages were determined by analysing a subsample of each polycarbonate filter by scanning electron microscopy. Counting methods, surface area, volume and biomass determinations and species identification in surface samples are detailed in Annett et al. (2010). Sea ice samples were analysed following identical protocols. Diatom census counts were also conducted on sediment trap material, according to the methods of Laws (1983) and Schrader and Gersonde (1978). Full details on slide preparation and diatom identification are as per Crosta et al. (2004). 


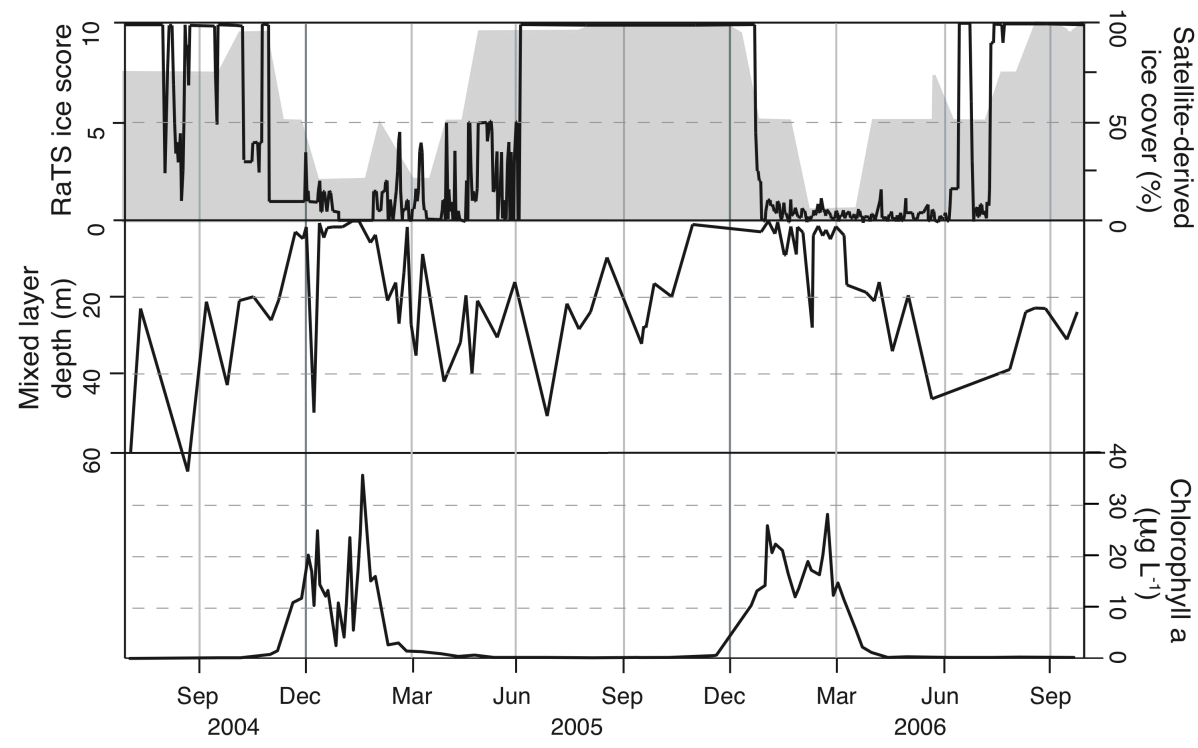

Fig. 2. Time-series plots of sea ice cover (top panel) with the black line representing daily observations in Ryder Bay and the shaded region representing regional sea ice cover of Marguerite Bay (from National Ice Centre - National Oceanic and Atmosphere Administration, Bellingshausen-Amundsen Sea region sea ice cover satellite data, available online: http://www.natice.noaa.gov); mixed layer depth (see text for definition; middle panel); and chlorophyll $a$ concentrations from July 2004 to October 2006 at the RaTS site, water depth $15 \mathrm{~m}$ (bottom panel). Data courtesy of the British Antarctic Survey, with supplementary data from this study.

\subsection{Sediment trap and core-top sediment $\delta^{13} C_{P O C}$ analysis}

After recovery of the sediment trap mooring arrays, the solution in each sample cup was allowed to settle, the supernatant siphoned off and the swimmers removed manually using $\mathrm{HCl}$-cleaned plastic forceps and a $\mathrm{x} 10$ dissecting binocular microscope. Each sample cup was then split into 10 fractions using a rotary splitter at the National Oceanography Centre (NOC), Southampton, UK.

One fraction from each sediment collection cup was washed, freeze-dried and ground for analysis of $\delta^{13} \mathrm{C}_{\mathrm{POC}}$. Duplicate $10 \mathrm{mg}$ aliquots of this dried sediment were weighed into silver capsules, acidified with $5 \% \mathrm{HCl}$ to remove carbonates and then dried at $60^{\circ} \mathrm{C}$ overnight. Decarbonated samples were then analysed for $\delta^{13} \mathrm{C}_{\mathrm{POC}}$ using a VG PRISM III isotope ratio mass spectrometer. One sub-core of each box core was prepared and analysed for $\delta^{13} \mathrm{C}_{\mathrm{POC}}$ in the same way as the sediment trap cup fraction.

\subsection{Data analysis and statistics}

All statistical analyses were performed using $\mathrm{R}$ computing software. Relevant information for each analysis is summarised in Appendix Table 1, in the order in which results appear in the text, and given due consideration in the discussion that follows.

\section{Results}

\subsection{Seasonal sea ice cover and productivity}

Sea ice cover, mixed layer depth and chlorophyll $a$ data from the austral summer growing seasons of 2004/05 and 2005/06 are presented in Fig. 2. Total sea ice cover was variable between the two seasons at the RaTS site, with full cover occurring for 138 days from 16 June to 1 November during winter 2004 and 198 days from 10 June to 25 December 2005. The mixed layer depth data show typical seasonality for Ryder Bay, with a deep winter mixed layer and a shallow surface layer in summer, influenced heavily by sea ice and surrounding glaciers (Meredith et al., 2004). Mixed layer depth is defined as the depth at which $\sigma_{0}=\sigma_{0}$ (surface) +0.05 (Barth et al., 2001), where $\sigma_{0}$ is the potential density anomaly $=$ $\rho-1000$, and $\rho$ is density in $\mathrm{kg} \mathrm{m}^{-3}$. A stratified surface ocean during summer reduces wind-induced vertical mixing and provides a stable environment for proliferation of diatom blooms and resultant seasonal drawdown of macro- and micronutrients (Clarke et al., 2008). In this study, both growing seasons lasted $\sim 4$ months, but the 2005/06 phytoplankton bloom occurred around 6 weeks later in accordance with later sea ice retreat. Summer surface water conditions were also much more stable in 2005/06 with a longer period characterised by a shallow mixed layer, in agreement with more persistent sea ice cover during the preceding winter. 


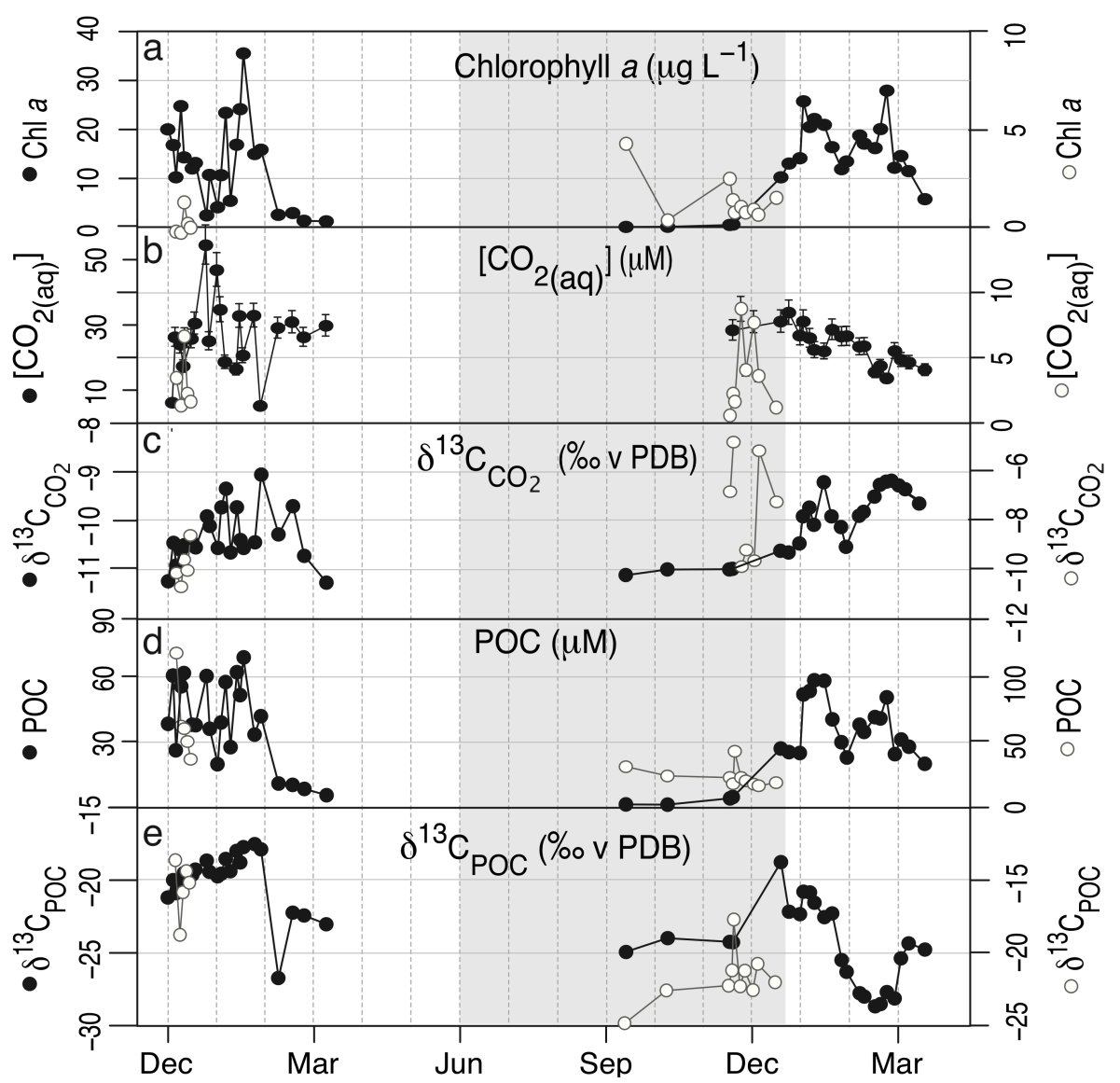

Fig. 3. Surface water (closed symbols) and sea ice (open symbols) time-series plots of (a) Chlorophyll $a(\mathbf{b})\left[\mathrm{CO}_{2}(\mathrm{aq})\right](\mathbf{c}) \delta^{13} \mathrm{C}_{\mathrm{CO}_{2}}(\mathbf{d}) \mathrm{POC}$ and (e) $\delta^{13} \mathrm{C}_{\mathrm{POC}}$ between December 2004 and April 2006. Error bars on $\left[\mathrm{CO}_{2}\right.$ (aq)] depict $11 \%$ maximum error associated with calculation using the CO2SYS programme. Note different scales for sea ice (right hand y-axis) and surface water (left hand y-axis). The period of full sea ice cover is indicated by grey shading. All water samples are from $15 \mathrm{~m}$ depth.

\subsection{Dissolved carbon dioxide and $\delta^{13} \mathrm{C}_{\mathrm{CO}_{2}}$ in surface waters and sea ice}

The concentration of $\mathrm{CO}_{2}$ and $\delta^{13} \mathrm{C}_{\mathrm{CO}_{2}}$ in surface waters show a general trend of $\left[\mathrm{CO}_{2(a q)}\right]$ decrease and ${ }^{13} \mathrm{C}$ enrichment during spring and summer during both summer seasons (Fig. 3). During the 2004/05 season, $\left[\mathrm{CO}_{2(a q)}\right]$ decreased from values as high as $54.2 \pm 6.0 \mu \mathrm{M}$ to $5.1 \pm 0.6 \mu \mathrm{M}$ whilst $\delta^{13} \mathrm{C}_{\mathrm{CO}_{2}}$ values rose from -11.2 to $-9.0 \%$. Similarly during the 2005/06 season, $\left[\mathrm{CO}_{2(a q)}\right]$ decreased from a high winter value of $33.7 \pm 3.7 \mu \mathrm{M}$ to $13.6 \pm 1.5 \mu \mathrm{M}$ and $\delta^{13} \mathrm{C}_{\mathrm{CO}_{2}}$ values rose from -11.1 to $-9.2 \%$. Important to note however, is that the 2004/05 season was characterised by rapid and large fluctuations in $\left[\mathrm{CO}_{2(a q)}\right]$; in fact, season maximum concentration occurs after the first chlorophyll peak in the middle of the growing season. Conversely, $\left[\mathrm{CO}_{2(a q)}\right]$ shows a much more systematic reduction over the duration of the 2005/06 growing season, albeit with a lesser overall drawdown. Similarly, $\delta^{13} \mathrm{C}_{\mathrm{CO}_{2}}$ shows much more variability in 2004/05 than the gradual increase seen in summer 2005/06. The greater variability seen in the 2004/05 season depicts regular inputs of $\mathrm{CO}_{2}$, which resulted in small negative shifts in $\delta^{13} \mathrm{C}_{\mathrm{CO}_{2}}$ to values as low as $-10.5 \%$ o during January and February 2005. The absence of such fluctuations in $\delta^{13} \mathrm{C}_{\mathrm{CO}_{2}}$ during summer $2005 / 06$ shows that there is no regular mid-season input of $\mathrm{CO}_{2}$. However, there is one marked increase in $\left[\mathrm{CO}_{2(a q)}\right]$ and simultaneous decrease in $\delta^{13} \mathrm{C}_{\mathrm{CO}_{2}}$, which provides evidence for a one-off mid-season input of $\mathrm{CO}_{2}$, coincident with a mid-season chlorophyll reduction between two periods of greater phytoplankton productivity.

The $\delta^{13} \mathrm{C}_{\mathrm{CO}_{2}}$ in sea ice is generally enriched relative to surface waters and exhibits greater temporal variability, with values ranging from -10.7 to $-4.8 \%$ (Fig. 3). $\mathrm{CO}_{2}$ concentrations in sea ice brine are lower than in surface waters, consistent with higher $\delta^{13} \mathrm{C}_{\mathrm{CO}_{2}}$. In addition to temporal variability in $\left[\mathrm{CO}_{2(a q)}\right]$ and $\delta^{13} \mathrm{C}_{\mathrm{CO}_{2}}$, the greater variability seen here than in surface water samples is partly spatial, as is common in sea ice brine (Rau et al., 1992; Kennedy et al., 2002) since samples were taken from different locations in the study area according to availability of ice. 
a) Surface water

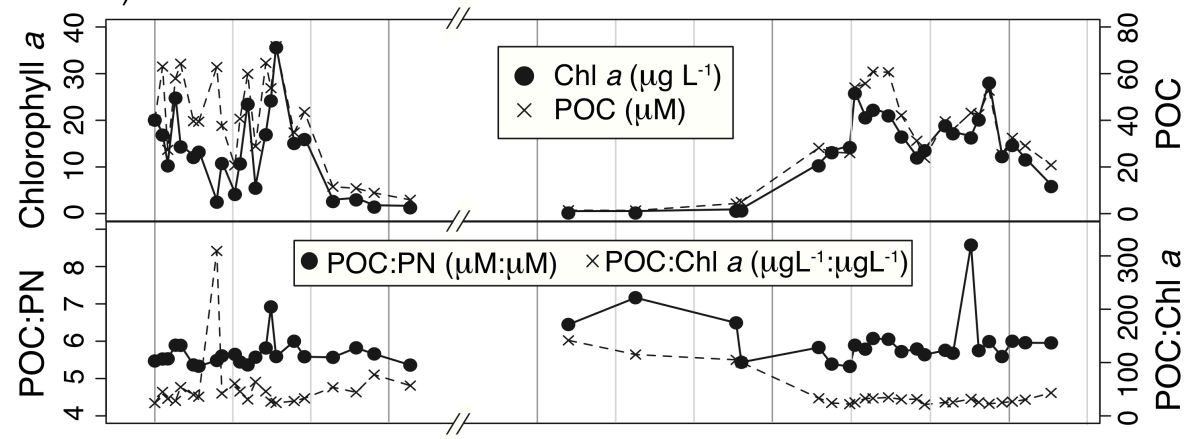

b) Sea ice brine

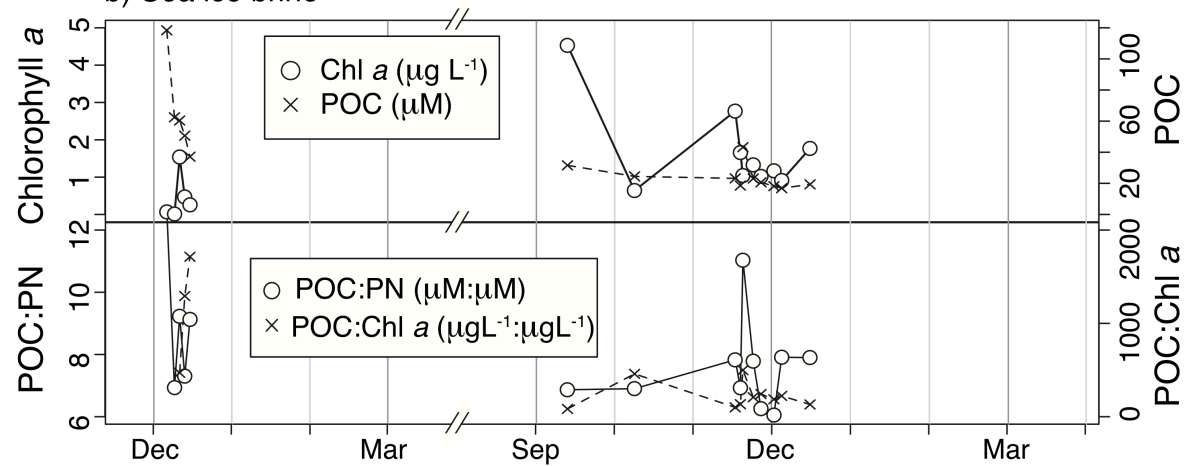

Fig. 4. Time series plots of chlorophyll $a$ concentration, POC concentration, POC:PN and POC:chl $a$ in (a) surface water and (b) sea ice from December 2004 to April 2006.

\subsection{Particulate organic carbon in surface waters and sea ice}

Concentrations of POC in Ryder Bay surface waters mimic levels of chlorophyll $a$ and show similar variability over summer 2004/05 and gradual trends in 2005/06 as do $\left[\mathrm{CO}_{2(a q)}\right]$ and $\delta^{13} \mathrm{C}_{\mathrm{CO}_{2}}$ (Fig. 3). However, surface water $\delta^{13} \mathrm{C}_{\mathrm{POC}}$ shows high inter-annual variability between the two growing seasons. During the $2004 / 05$ season, $\delta^{13} C_{\text {POC }}$ increases gradually over the course of the phytoplankton bloom from -21.2 to $-17.9 \%$ o, with a small $\sim 1 \%$ o decrease in $\delta^{13} \mathrm{C}_{\mathrm{POC}}$ during late December 2004 when chlorophyll $a$ declined and $\left[\mathrm{CO}_{2(a q)}\right]$ increased. In February 2005, when chlorophyll $a$ began to decline at the end of the growing season, a large yet short-lived $\sim 9 \%$ negative shift is observed in $\delta^{13} \mathrm{C}_{\mathrm{POC}}$ to a season-low of $-26.7 \%$. This occurs in concert with an increase in $\left[\mathrm{CO}_{2(a q)}\right]$ of $\sim 8 \mu \mathrm{M}$ and a decrease in $\delta^{13} \mathrm{C}_{\mathrm{CO}_{2}}$ of $\sim 1.2 \%$. At the end of the growing season, $\delta^{13} \mathrm{C}_{\mathrm{POC}}$ returned to a near winter value of $\sim-23 \%$. During the 2005/06 growing season, $\delta^{13} \mathrm{C}_{\mathrm{POC}}$ increased from a winter low of $\sim$ $25 \%$ in September 2005 to a season high of $-18.8 \%$ in December 2005 just prior to sea ice retreat. Once the open water spring phytoplankton bloom was underway, $\delta^{13} \mathrm{C}_{\mathrm{POC}}$ was consistently around $-21 \%$ until there was an injection of $\sim 7 \mu \mathrm{M} \mathrm{CO}_{2}$ into the system during late January and concomitant decreases in $\delta^{13} \mathrm{C}_{\mathrm{CO}_{2}}$ and $\delta^{13} \mathrm{C}_{\mathrm{POC}}$ of $0.7 \%$ and $\sim 2 \%$, respectively. In late January and early February 2006, at the commencement of the second chlorophyll $a$ peak, there was a large negative shift in $\delta^{13} \mathrm{C}_{\mathrm{POC}}$ of $\sim 10 \%$ o to values as low as $-28.7 \%$ (Fig. 3). This negative shift in $\delta^{13} \mathrm{C}_{\mathrm{POC}}$ was maintained throughout the second chlorophyll $a$ peak and once chlorophyll had declined at the end of the growing season, towards the end of March 2006, the $\delta^{13} \mathrm{C}_{\mathrm{POC}}$ returned to a typical winter value of $-25 \%$. In agreement with this large and prolonged negative isotopic transition, a seasonal POC concentration-weighted average $\delta^{13} \mathrm{C}_{\mathrm{POC}}$ of $24.5 \%$ was significantly lower for 2005/06 than the 2004/05 season average of $-20.0 \%$ (2-sample t-test $p<0.001)$.

POC:PN ratios of suspended material averaged 5.8 indicating a wholly marine origin, as would be expected at a site like Ryder Bay, due to the relative paucity of terrestrial organic matter in the vicinity (Fig. 4a). The dominant marine phytoplankton source of Ryder Bay organic matter is confirmed by POC:chl $a<200$ in the vast majority of suspended samples.

Sea ice POC:PN is highly variable throughout the season of sea ice coverage, but an average value of 10 is higher than in surface waters (Fig. 4b). Most of our values for POC:chl $a$ in sea ice range from 83.7 to 497.0 (Fig. 4b) and therefore fall within the range of POC:chl $a$ values found in previous studies of marine biota (Eppley et al., 1973; Pollehne et al., 1993) and sea ice algal assemblages (Gleitz and Thomas, 1993). We also observe significantly higher POC:chl $a$ values of 1250 to 1750 in late-December 2004. Conversely, at 
a) Surface water

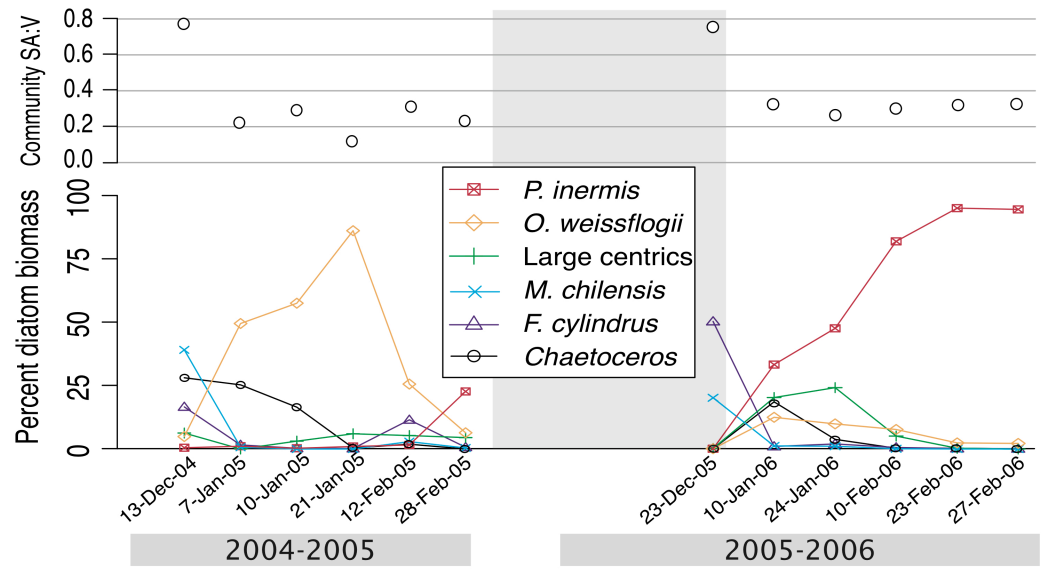

b) Sea-ice brine

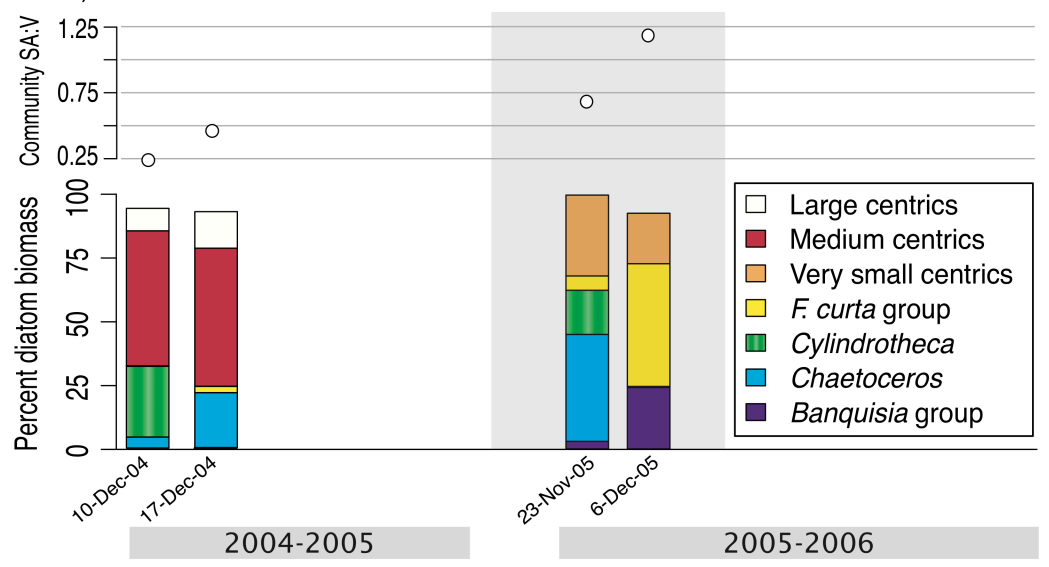

Fig. 5. Time-series analysis of diatom assemblages for (a) surface waters and (b) sea ice brine, presented as percentage of total diatom biomass. Upper panel dots show community SA:V. Species/groups shown are the Banquisia group (as defined in Annett et al., 2010), Chaetoceros (Hyalochaeta subgenus), Fragilariopsis curta group (see text), Fragilariopsis cylindrus, Minidiscus chilensis, Odontella weissflogii and P. inermis. Size fractions of centric diatoms are $<10 \mu \mathrm{m}, 20$ to $50 \mu \mathrm{m}$ and $>50 \mu \mathrm{m}$, for very small, medium and large cells, respectively. The very small fraction is likely comprised of Thalassiosira auxospores, while other centric size classes are predominantly Thalassiosira species but also include species from the genera Actinocyclus Porosira and Stellarima.

the beginning of the 2004/05 season, we find sea ice POC:chl $a$ values of $>20000$ (not shown in Fig. 4). We attribute these values to extremely low chlorophyll levels, close to the detection limit of the technique (Fig. 4b), which as the denominator drive POC:chl $a$ ratios unrealistically high. As such, we consider these values to be erroneous and discount them from further consideration.

\subsection{Diatom assemblages and size classes}

The surface water phytoplankton bloom in Ryder Bay is typically dominated by the microplankton fraction $(>20 \mu \mathrm{m})$, so large solitary or chain-forming diatoms dominate over the smaller nanoplankton and picoplankton (Clarke et al., 2008). Diatom assemblages show distinct changes throughout the two growing seasons in surface waters and sea ice (Fig. 5; Annett et al., 2010). Briefly, diatom biomass in 2004/05 was initially relatively diverse, with substantial contributions from Minidiscus chilensis and Chaetoceros (Hyalochaeta subgenus) species. Mid-season assemblages were dominated by Odontella weissflogii, accounting for up to $80 \%$ of the estimated diatom community. Late-season assemblages returned to a more diverse composition. The early part of the 2005/06 season showed a mixed diatom assemblage, consisting largely of Fragilariopsis cylindrus, large and medium centrics ( $>50 \mu \mathrm{m}$ and 20 to $50 \mu \mathrm{m}$, respectively) and a small contribution from Proboscia inermis. A shift towards the almost complete dominance of $P$. inermis occurred at the time of the late-season negative excursion in $\delta^{13} \mathrm{C}_{\mathrm{POC}}$. In both seasons, surface area to volume ratios $(\mathrm{SA}: \mathrm{V})$ estimated for the diatom community are initially high $\left(\sim 0.76 \mu \mathrm{m}^{2}: \mu \mathrm{m}^{3}\right)$ and decline thereafter $\left(0.2\right.$ to $\left.0.3 \mu \mathrm{m}^{2}: \mu \mathrm{m}^{3}\right)$. More variability is seen in SA:V in 2004/05 than in 2005/06, in accordance with the more diverse assemblages in the earlier season. 

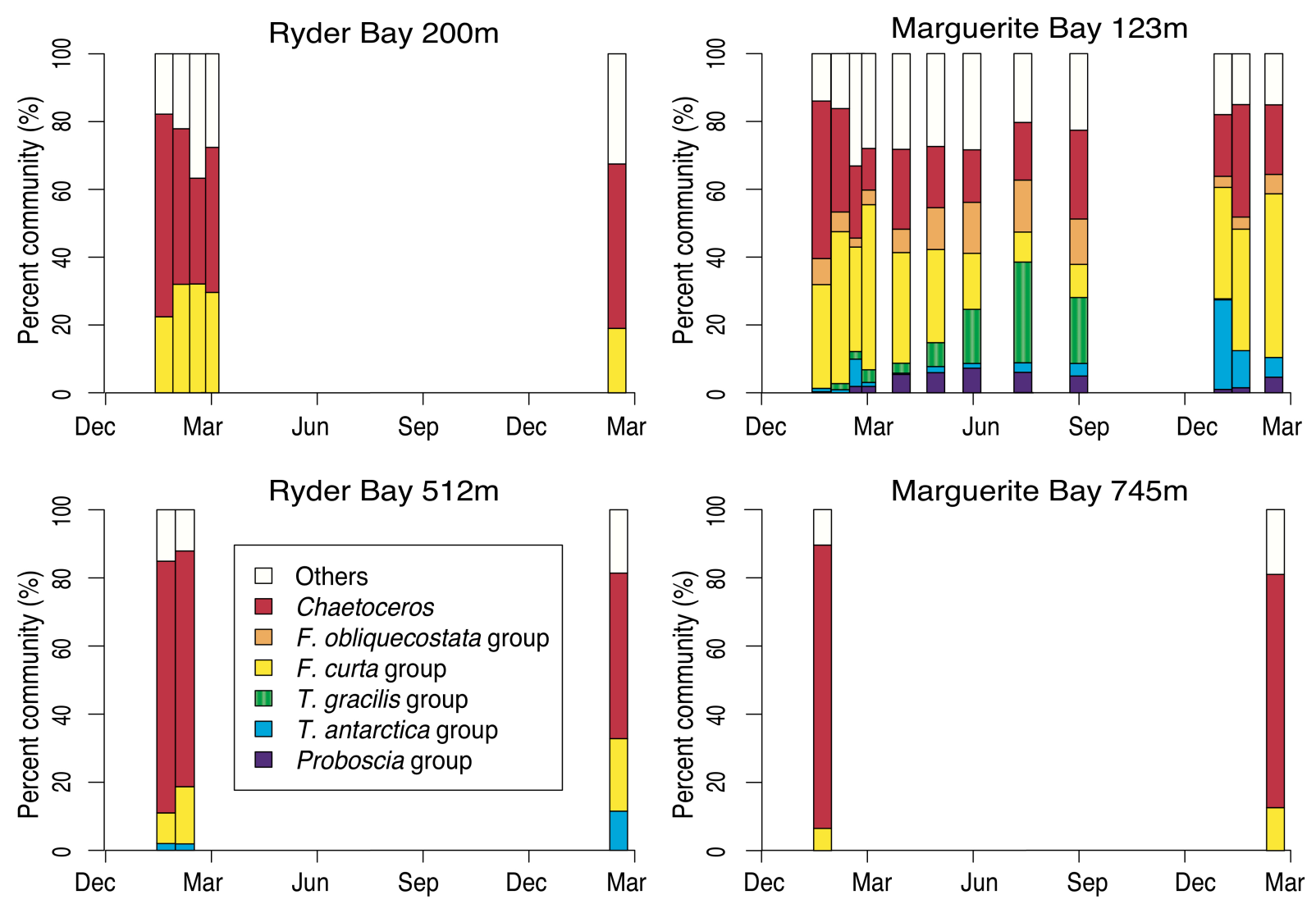

Fig. 6. Time-series plots of diatom species composition in sediment traps between December 2004 and March 2006, location and depth of traps as described on each plot.

In sea ice, we observe less species variability than in surface waters (Fig. 5). In December 2004, sea ice biomass is made up of medium centric groups, such as Porosira and Thalassiosira species. In the 2005/06 season, sea ice diatom assemblages were dominated initially by Chaetoceros simplex and very small centric species $(<10 \mu \mathrm{m})$. In early December 2005, the main contribution comes from the Fragilariopsis curta group, primarily F. cylindrus but also F. curta.

Diatom census counts in the sediment traps show that species composition at depth is broadly similar to that in surface waters, but with different proportions of each species (Fig. 6), presumably a result of differential dissolution during sinking through the water column. Shallow traps are dominated by cold water species such as the F. curta and Chaetoceros groups, although higher resolution sampling in Marguerite Bay shows minor contributions from the F. obliquecostata group and Thalassiosira spp. throughout the sampling period. Both deeper traps are overwhelmingly dominated by Chaetoceros with minor contributions from F. curta and $T$. antarctica groups. P. inermis abundance was low in all sediment traps throughout the study period.

\subsection{Sinking particulate organic carbon}

Sediment trap carbon flux and $\delta^{13} \mathrm{C}_{\mathrm{POC}}$ data from Ryder Bay and Marguerite Bay are shown in Fig. 7, and Table 1 provides a summary of sediment trap isotopic data. Carbon fluxes were highly variable between traps and between seasons, but the Ryder Bay traps show greater overall export than the Marguerite Bay traps (Fig. 7). There is no significant change in seasonal flux-weighted average $\delta^{13} \mathrm{C}_{\mathrm{POC}}$ with water depth at either mooring site in either growing season.

Seasonal variability in surface water $\delta^{13} \mathrm{C}_{\mathrm{POC}}$ is, to some extent, reflected in the sediment trap data (Fig. 7). During the $2004 / 05$ season, surface water $\delta^{13} \mathrm{C}_{\mathrm{POC}}$ ranged from $21.2 \%$ to $-17.5 \%$ from early December to the beginning of February (Fig. 3). Whilst this $4 \%$ enrichment is not fully expressed in the sediment trap data, we do see a slight $\delta^{13} \mathrm{C}_{\mathrm{POC}}$ increase in the RaTS $200 \mathrm{~m}$ sediment trap from $-20.7 \%$ to $-19.7 \%$ between late January and late February. We see a more pronounced negative shift to $-22.5 \%$ in sediment $\operatorname{trap} \delta^{13} \mathrm{C}_{\mathrm{POC}}$ at the beginning of March 2005, approximately one month after the negative shift in surface $\delta^{13} \mathrm{C}_{\mathrm{POC}}$ to $26.7 \%$ observed at the beginning of February 2005. A similar response is not observed in the Marguerite Bay traps, possibly due to different diatom assemblages in the more open 

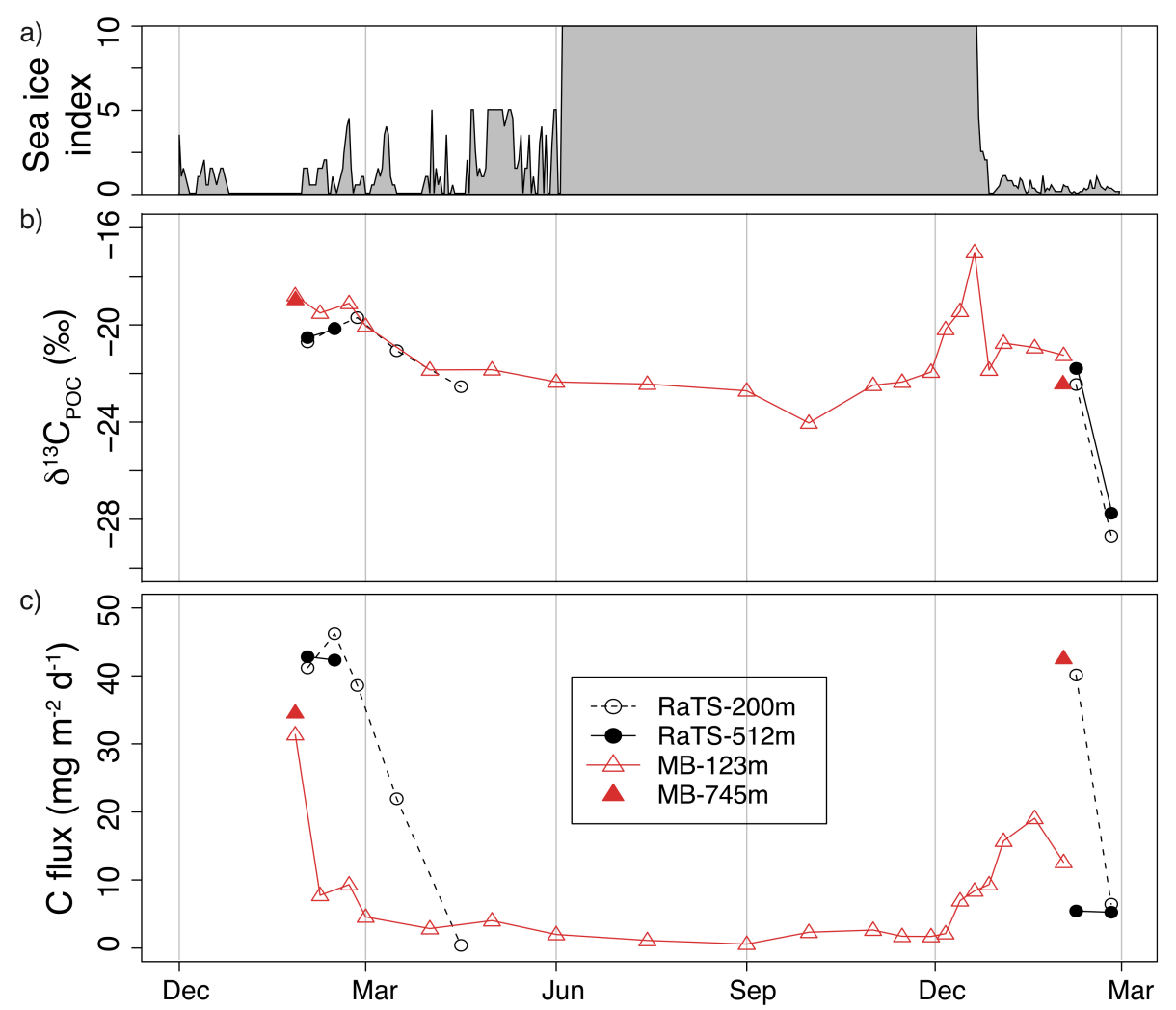

Fig. 7. $\delta^{13} \mathrm{C}_{\mathrm{POC}}$ and carbon (C) flux data from time-series sediment traps from December 2004 until March 2006, as per legend. RaTS is the trap mooring at the routine sampling site in Ryder Bay, MB is the deeper trap mooring in Marguerite Bay. The top panel shows sea ice coverage as measured daily in Ryder Bay (data from the British Antarctic Survey). Maximum error on sediment trap $\delta^{13} \mathrm{C}_{\mathrm{POC}}$ values is $1.0 \%$ associated with formaldehyde preservation (Mincks et al., 2008) since this vastly exceeds analytical error.

Table 1. Sediment trap seasonal flux-weighted average $\delta^{13} \mathrm{C}_{\mathrm{POC}}$ presented in \%o versus VPDB; maximum error quoted as the $1.0 \%$ uncertainty associated with formaldehyde preservation (Mincks et al., 2008), as this vastly exceeds analytical error.

\begin{tabular}{lll}
\hline Trap & $\begin{array}{l}\delta^{13} \mathrm{C}_{\mathrm{POC}} \\
(2004 / 05)\end{array}$ & $\begin{array}{l}\delta^{13} \mathrm{C}_{\mathrm{POC}} \\
(2005 / 06)\end{array}$ \\
\hline RaTS 200 m & $-20.3 \pm 1.0$ & $-23.3 \pm 1.0$ \\
RaTS 512 m & $-20.4 \pm 1.0$ & $-24.7 \pm 1.0$ \\
MB 123 m & $-19.1 \pm 1.0$ & $-20.5 \pm 1.0$ \\
MB 745 m & $-19.1 \pm 1.0$ & $-22.3 \pm 1.0$ \\
\hline
\end{tabular}

ocean site that do not have the same effect on $\delta^{13} \mathrm{C}_{\mathrm{POC}}$ as the coastal site.

As in surface waters, 2005/06 sediment trap data show very different $\delta^{13} C_{\text {POC }}$ characteristics to those from 2004/05. Although data are somewhat sparse for the Ryder Bay trap, they do highlight a similar negative transition to very low $\delta^{13} C_{\mathrm{POC}}$ values at the end of the $2005 / 06$ growing season as seen in surface values. In surface waters, $\delta^{13} \mathrm{C}_{\mathrm{POC}}$ undergoes a large negative shift at the end of January to $-28.7 \%$. Al- though there is a time lag, the same negative shift is seen in late February in the $200 \mathrm{~m}$ RaTS trap $\left(\delta^{13} \mathrm{C}_{\mathrm{POC}}=-28.7 \%\right.$ o $)$ and the $512 \mathrm{~m}$ trap, where $\delta^{13} \mathrm{C}_{\mathrm{POC}}$ drops from $-21.8 \%$ in early February to $-27.8 \%$ in late February (Fig. 7).

\section{Discussion}

\section{1 $\delta^{13} \mathrm{C}_{\mathrm{POC}}$ and $\left[\mathrm{CO}_{2(a q)}\right]$ in surface waters and sea ice}

According to the classic $\mathrm{CO}_{2}-\delta^{13} \mathrm{C}_{\mathrm{POC}}$ relationship (François et al., 1993), we would expect $\delta^{13} \mathrm{C}_{\mathrm{POC}}$ to vary depending on the balance between supply and demand of the photosynthetic carbon source. This supply and demand model is regulated by two steps in the photosynthetic process: transport of the inorganic carbon reactant into the internal cell carbon pool and subsequent fixation to organic carbon (Popp et al., 1999; Trull and Armand, 2001). According to this model, an increase in external $\left[\mathrm{CO}_{2(a q)}\right]$ would increase the fractionation factor $\left(\varepsilon_{p}\right)$ of inorganic carbon assimilation and decrease $\delta^{13} \mathrm{C}_{\mathrm{POC}}$, independent of the initial $\delta^{13} \mathrm{C}_{\mathrm{CO}_{2}}$ (François et al., 1993; Rau et al., 1996; Burkhardt et al., 1999; Lourey et al., 2004). 


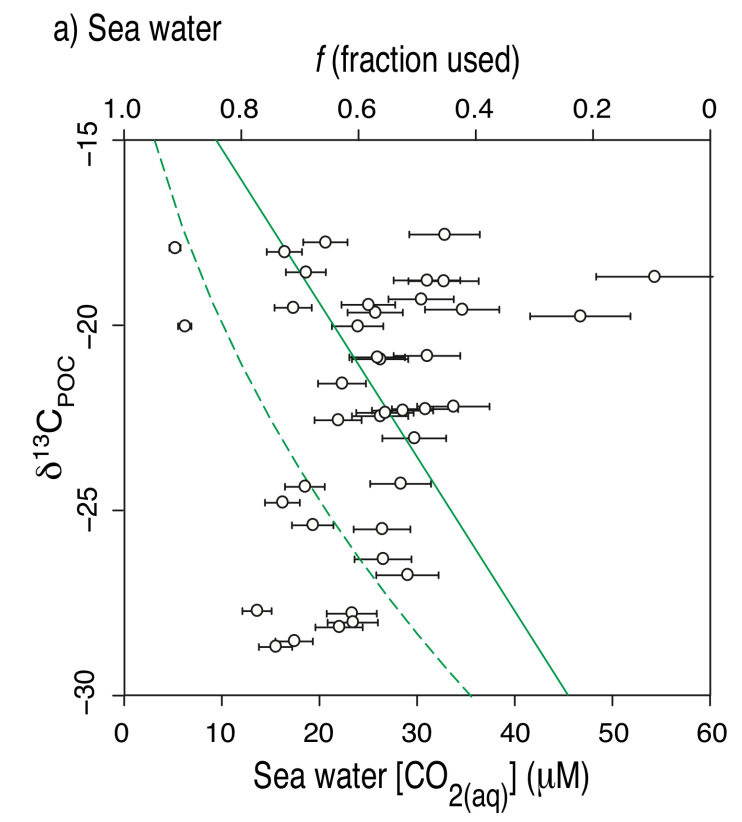

b) Sea ice brine

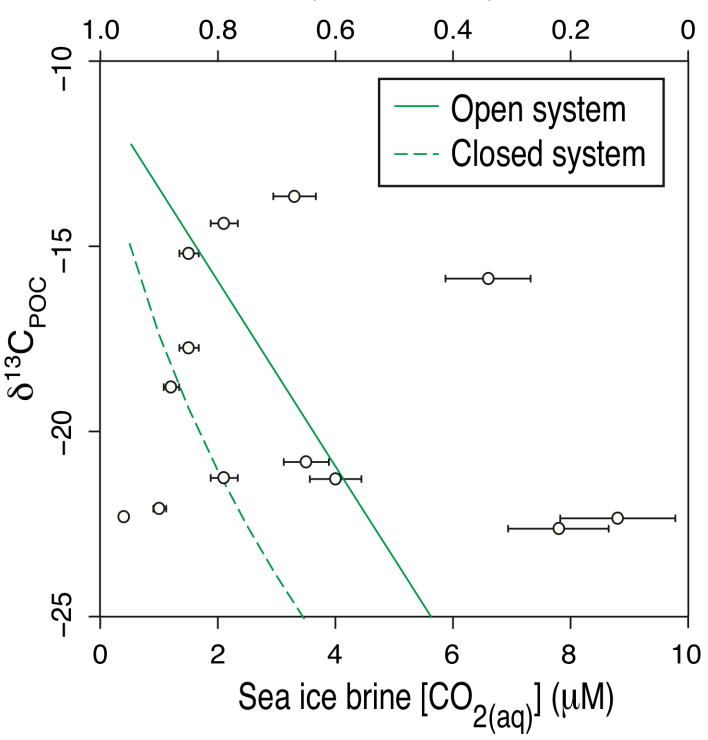

Fig. 8. $\delta^{13} \mathrm{C}_{\mathrm{POC}}$ versus $\left[\mathrm{CO}_{2}(\mathrm{aq})\right]$ in (a) surface sea water and (b) sea ice brine. Open circles are data points observed. X-axis error bars depict $11 \%$ maximum error associated with $\left[\mathrm{CO}_{2}\right.$ (aq)] calculation using the CO2SYS programme. Solid lines show the modelled relationships between $\delta^{13} \mathrm{C}_{\mathrm{POC}}$ and $\left[\mathrm{CO}_{2}(\mathrm{aq})\right]$ under open system dynamics, where $\varepsilon_{p}=25 \%$. Dashed lines show modelled relationships under closed system dynamics, assuming an accumulated product and $\varepsilon_{p}=25 \%$. $f$ is fraction used compared to maximum values for $\mathrm{CO}_{2}$ (aq). A full explanation of equations used is in the text.

We investigate the influence of changing $\left[\mathrm{CO}_{2(a q)}\right]$ on $\varepsilon_{p}$ and $\delta^{13} \mathrm{C}_{\mathrm{POC}}$ in Fig. 8, which presents $\delta^{13} \mathrm{C}_{\mathrm{POC}}$ data from this study plotted against concurrent $\left[\mathrm{CO}_{2(a q)}\right]$ in sea water and sea ice brine, as well as theoretical relationships between $\delta^{13} \mathrm{C}_{\mathrm{POC}}$ and $\left[\mathrm{CO}_{2(a q)}\right]$. These theoretical relationships are based on $\varepsilon_{p}=25 \%$ which is within the commonly accepted range of maximum $\varepsilon_{p}$ values, 25 to $28 \%$ (Raven and Johnston, 1991; Goericke et al., 1994), and closed and open system isotope fractionation approaches. Open system isotopic evolution is calculated using Eq. (2), where $\delta^{13} \mathrm{C}_{\mathrm{CO}_{2}}$ ini is the initial isotopic value of reactant $\mathrm{CO}_{2}$, for which we use $11 \%$ o for surface water and sea ice. $f$ is the fraction of $\mathrm{CO}_{2}$ utilised compared to maximum values of $60 \mu \mathrm{M}$ in sea water and $10 \mu \mathrm{M}$ in sea ice (Fig. 3).

$\delta^{13} C_{\mathrm{POC}}=\delta^{13} C_{\mathrm{CO}_{2} \text { ini }}+\varepsilon_{p} f$

Closed system isotopic evolution is calculated using the Rayleigh accumulated product equation (Eq. 3).

$\delta^{13} C_{\mathrm{POC}}=\delta^{13} \mathrm{C}_{\mathrm{CO}_{2} \text { ini }}-\varepsilon_{p}\left(\frac{f \ln (f)}{(1-f)}\right)$

Unlike the strong negative correlation observed between $\delta^{13} \mathrm{C}_{\mathrm{POC}}$ and $\left[\mathrm{CO}_{2(a q)}\right]$ in open-ocean studies in the Southern Ocean (Lourey et al., 2004), we demonstrate no significant relationship in coastal sea ice or surface waters, assuming either closed or open system dynamics (Fig. 8). We see no correlation between observed $\delta^{13} \mathrm{C}_{\mathrm{POC}}$ and $\left[\mathrm{CO}_{2(a q)}\right]$ in surface water $\left(r^{2}=0.247 ; p=0.120\right)$ or sea ice $\left(r^{2}=0.200\right.$; $p=0.511)$ and the data clearly do not fit a modelled isotopic evolution at any value of $\varepsilon_{p}$ assuming closed or open system dynamics. $\delta^{13} \mathrm{C}_{\mathrm{CO}_{2}}$ can be excluded as a possible driver of the observed negative shifts in $\delta^{13} \mathrm{C}_{\mathrm{POC}}$, since a $\delta^{13} \mathrm{C}_{\mathrm{CO}_{2}}$ shift of only $-2.2 \%$ in surface waters cannot account for the large shift in $\delta^{13} \mathrm{C}_{\mathrm{POC}}$ of $\sim-10 \%$ (Fig. 3). Therefore, although some more subtle changes in $\delta^{13} \mathrm{C}_{\mathrm{POC}}$ are consistent with minor changes in $\left[\mathrm{CO}_{2(a q)}\right]$ and $\delta^{13} \mathrm{C}_{\mathrm{CO}_{2}}$ during biological uptake and/or nutrient injections, inorganic carbon availability is not the primary control on $\delta^{13} \mathrm{C}_{\mathrm{POC}}$ in sea ice or surface waters in Ryder Bay.

\subsection{Factors influencing $\delta^{13} C_{P O C}$ in surface waters}

Phytoplankton growth rates typically show a positive relationship with $\delta^{13} \mathrm{C}_{\mathrm{POC}}$, since higher growth rates increase carbon demand and restrict $\varepsilon_{p}$ (Laws et al., 1995; Rau et al., 1996; Popp et al., 1998; Burkhardt et al., 1999; Villinski et al., 2000; Trull et al., 2008). While growth rate data are not available for the study period, a role for algal growth rate cannot be ruled out. However, this would more likely be significant at the onset of the phytoplankton bloom and growth rate-related $\delta^{13} \mathrm{C}_{\mathrm{POC}}$ changes in iron-replete Southern Ocean environments typically account for up to $2 \%$ (Trull et al., 2008). Growth rate cannot therefore explain the full extent of the rapid late-season isotopic shifts seen in Ryder Bay. Since Ryder Bay surface waters do not conform to the widely published growth rate/[CO $\left.\mathrm{CO}_{2(a q)}\right]$ vs. $\delta^{13} \mathrm{C}_{\mathrm{POC}}$ relationship 


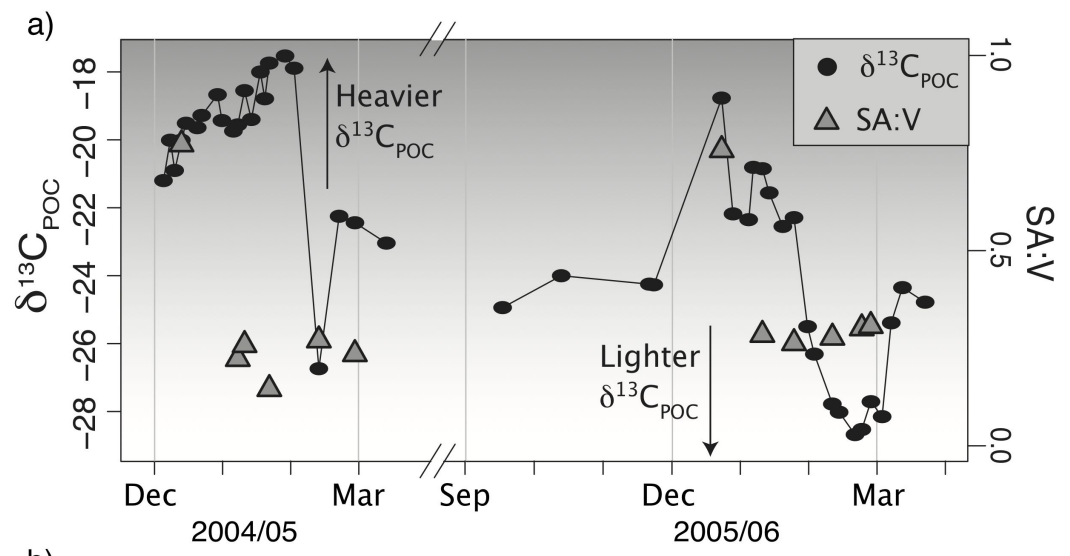

b)

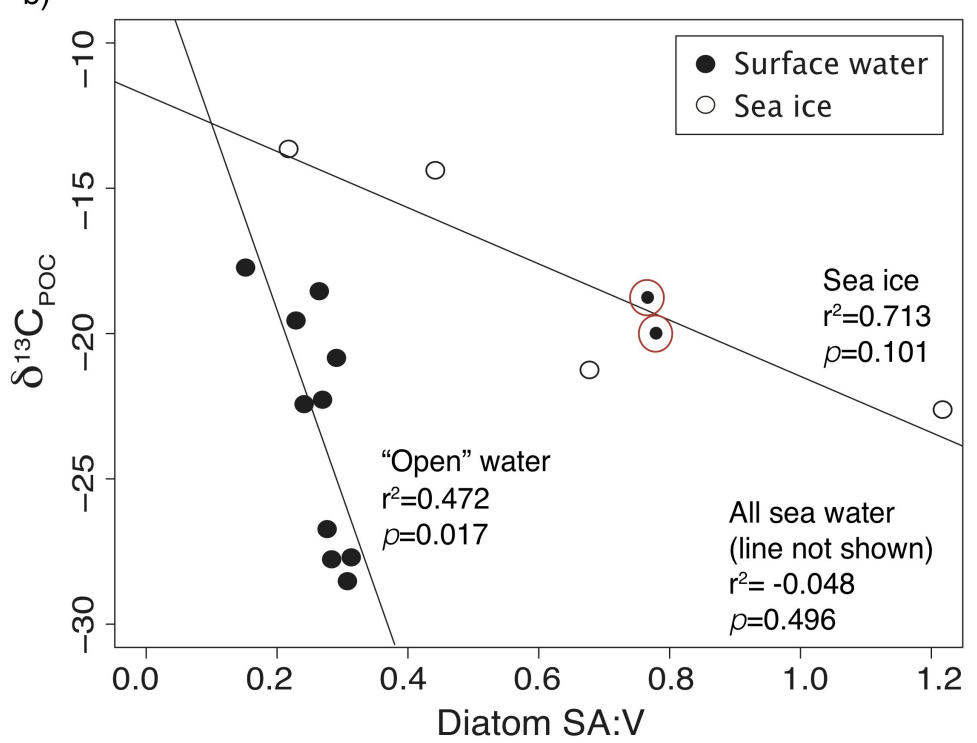

Fig. 9. Comparison of surface water diatom assemblage $\mathrm{SA}: \mathrm{V}$ ratio (triangles) with $\delta^{13} \mathrm{C}_{\mathrm{POC}}$ (circles) in time-series data (a) and regression analysis (b). Sea ice data are denoted in (b) by open symbols and sea water samples by filled symbols. The two water samples circled in (b) are early season samples postulated to be influenced by sea ice material and are not included in the "open" water regression line shown (see text).

(e.g. Jasper et al., 1994), an alternative mechanism must be driving the large decreases in $\delta^{13} \mathrm{C}_{\mathrm{POC}}$ observed in the latter part of the Ryder Bay growing seasons.

In this study, the largest demonstrated determinant on seasonal $\delta^{13} \mathrm{C}_{\mathrm{POC}}$ changes in surface waters is diatom assemblage. However, least-squares linear regression analysis shows that there is only a weak negative relationship between diatom SA:V and $\delta^{13} \mathrm{C}_{\mathrm{POC}}$, even when early season samples likely dominated by sea ice-derived organics (those plotting on the same line as sea ice samples) are excluded $\left(r^{2}=0.472 ; p=0.017\right.$, Fig. 9). Time-series data (Fig. 9) clearly show that whilst the negative excursions in $\delta^{13} \mathrm{C}_{\mathrm{POC}}$ are accompanied by slight changes in $\mathrm{SA}: \mathrm{V}$, there is no significant $\mathrm{SA}: \mathrm{V}$ control on $\delta^{13} \mathrm{C}_{\mathrm{POC}}$. We deduce therefore that in contrast to Popp et al. (1998, 1999), Burkhardt et al. (1999) and Trull and Armand (2001), diatom species control of $\delta^{13} \mathrm{C}_{\mathrm{POC}}$ is not related to cell size or SA:V in this study, but rather that these parameters are all responding to an additional factor.

The most striking change in surface water diatom assemblages concurrent with the large negative shift in $\delta^{13} \mathrm{C}_{\mathrm{POC}}$ is the shift to near total dominance of Proboscia species, particularly $P$. inermis, during the second chlorophyll peak of summer 2005/06 (Fig. 10). Least-squares linear regression analysis reveals an extremely significant relationship $\left(r^{2}=0.968 ; p=0.000243\right)$ between the percentage of total biomass made up of $P$. inermis and $\delta^{13} C_{\mathrm{POC}}$ for $2005 / 06$. Although diatom species changes appear to have a much greater effect on $\delta^{13} \mathrm{C}_{\mathrm{POC}}$ during the 2005/06 season when $P$. inermis makes a significantly greater contribution to total diatom biomass, the relatively high abundance $(21 \%)$ of $P$. inermis in one sample of the 2004/05 growing season also seems related to isotopically lighter POC $(-22.4 \%$ ). However, presence of $P$. inermis cannot explain the lowest value 


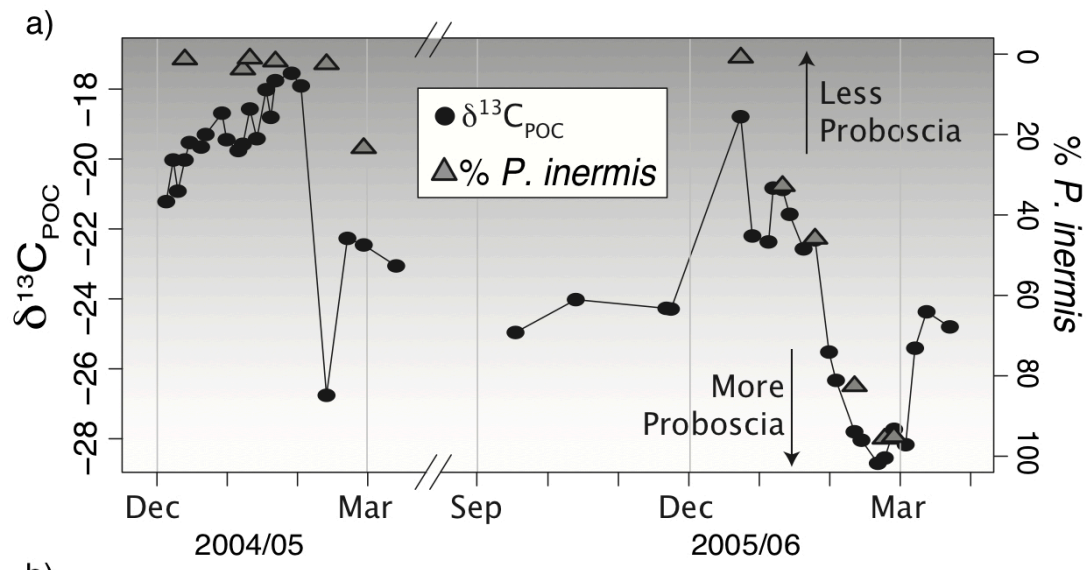

b)

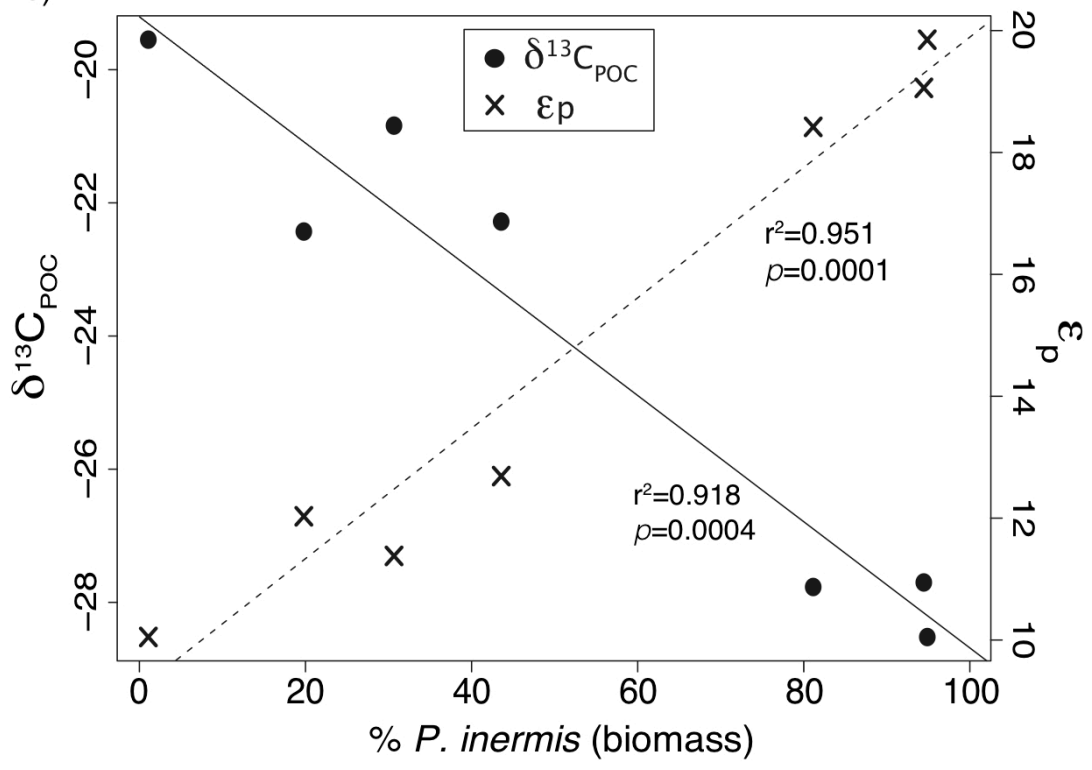

Fig. 10. Comparison of the fraction of surface water diatom biomass made up of $P$. inermis (triangles), $\delta^{13} \mathrm{C}_{\mathrm{POC}}\left(\mathrm{circles}\right.$; solid line) and $\varepsilon_{p}$ (crosses; dashed line) for 2004/05 and 2005/06. Time-series data is shown in (a), note the reversal of the right hand y-axis (\% P. inermis) to better illustrate the coupling between $P$. inermis biomass and $\delta^{13} \mathrm{C}_{\mathrm{POC}}$. Variation of $\delta^{13} \mathrm{C}_{\mathrm{POC}}$ and $\varepsilon_{p}$ vs. $P$. inermis biomass for all 2005/6 samples and the only sample from 2004/5 where $P$. inermis accounts for $>2 \%$ of total biomass are shown in (b).

of the season $(-26.7 \%$ o on 12 February 2005. Least-squares linear regression analysis on all samples where $P$. inermis is expected to exert a significant control on $\delta^{13} \mathrm{C}_{\mathrm{POC}}$ ( $>2 \%$ of total biomass) shows a very strong relationship between $P$. inermis abundance and $\delta^{13} \mathrm{C}_{\mathrm{POC}}\left(r^{2}=0.918\right.$; $p=0.000423$, Fig. 10) and therefore suggests that the majority of $\delta^{13} \mathrm{C}_{\mathrm{POC}}$ variability can be attributed to species effects. Similar biomass dominance by $O$. weissflogii in 2004/5 corresponds with no appreciable shift in $\delta^{13} \mathrm{C}_{\mathrm{POC}}$ to either lighter or heavier values, so we argue that species-specific effects on $\delta^{13} \mathrm{C}_{\mathrm{POC}}$ are not exerted by all diatom species in Ryder Bay. Instead, it is the unusual biochemistry of $P$. inermis that drives distinct negative shifts to $\delta^{13} \mathrm{C}_{\mathrm{POC}}$ values as low as $-29 \%$ in this study.
Proboscia diatoms are known to synthesise a unique set of long-chain 1,14-diols and 12-hydroxy methyl alkanoates with strongly depleted carbon isotope signatures of $<-32 \%$ and $<-34 \%$, respectively (Sinninghe Damsté et al., 2003). While these Proboscia lipids can contribute up to $35 \%$ of total lipid flux in sediment traps (Wakeham et al., 2002), it is unlikely that they alone account for the low $\delta^{13} \mathrm{C}_{\mathrm{POC}}$ signatures seen in this study, as they typically make up less than $1 \%$ of total organic carbon (raw data from Wakeham et al. (2002), published online at http://usjgofs.whoi.edu/PI-NOTES/arabian/ Wakeham/sedtrap_lipid_raw.html). However, the ${ }^{13} \mathrm{C}$ depletion of these lipids is greater than those of alkenones from haptophytes or dinosterol from dinoflagellates and points to a substantially depleted pool of intracellular carbon in 
Proboscia spp. not readily explained by factors such as SA:V (Sinninghe Damsté et al., 2003). Sinninghe Damsté et al. (2003) found that all Proboscia species analysed synthesised these "Proboscia lipids", thus it is likely that the potential influence on $\delta^{13} \mathrm{C}_{\mathrm{POC}}$ is not limited to $P$. inermis. Accordingly, samples in this study where other Proboscia species were observed (Proboscia truncata), albeit at low abundances, fall on the same trend presented in Fig. 10 and least-squares linear regression analysis yields an almost identical $r^{2}$ value as for $P$. inermis alone $\left(r^{2}=0.922, p=\right.$ 0.00037; data not shown). However, the Proboscia bloom presented here was overwhelmingly dominated by $P$. inermis, so we restrict our conclusions regarding species effects to this species.

A detailed examination of why the internal carbon pool of P. inermis is so depleted is beyond the scope of this study. However, we suggest that carbon concentrating mechanisms (CCMs) employed by many diatom species to buffer the impacts of variability in $\left[\mathrm{CO}_{2(a q)}\right]$ may play an important role in the species-related differences in $\delta^{13} \mathrm{C}_{\mathrm{POC}}$ seen here (Sharkey and Berry, 1985; Descolas-Gros and Fontugne, 1985; Goericke et al., 1994; Laws et al., 1995).

Phytoplankton employing typical $\mathrm{C} 3$ biochemistry in the absence of CCMs, i.e. diffusive $\mathrm{CO}_{2}$ transfer to the internal cell carbon pool and eukaryotic Rubisco carboxylation (Kerby and Raven, 1985), fractionate $\mathrm{CO}_{2}$ by $\sim 29 \%$ and produce organic carbon of -25 to $-30 \%$ (Raven et al., 1994). We propose therefore that $P$. inermis utilises a simple $\mathrm{C} 3$ photosynthetic pathway with no employment of CCMs. An additional contribution to low $\delta^{13} \mathrm{C}_{\mathrm{POC}}$ values associated with $P$. inermis may arise from the production of isotopically light "Proboscia lipids".

Why a more mixed phytoplankton assemblage prior to the bloom of $P$. inermis coincides with higher $\delta^{13} \mathrm{C}_{\mathrm{POC}}(-25$ to $-15 \%$ ) remains unclear. However, direct active $\mathrm{HCO}_{3}^{-}$uptake, which is significant in the marine environment (Tortell et al., 1997, 2006; Cassar et al., 2004;), can drive $\delta^{13} \mathrm{C}_{\mathrm{POC}}$ to values $>-10 \%$ o (Raven, 1997 and references therein), since $\mathrm{HCO}_{3}^{-}$is isotopically enriched relative to $\mathrm{CO}_{2}$ by approximately $12 \%$ at $0^{\circ} \mathrm{C}$ (Deines et al., 1974; Mook et al., 1974). $\mathrm{HCO}_{3}^{-}$utilisation mediated by phosphoenolpyruvate carboxylase (PEPC) would also drive $\delta^{13} \mathrm{C}_{\mathrm{POC}}$ relatively high due to a much smaller $\varepsilon_{p}$ than the initial $\mathrm{HCO}_{3}^{-}$enrichment relative to $\mathrm{CO}_{2}$ (O'Leary, 1981; O'Leary et al., 1992). We speculate therefore that higher $\delta^{13} \mathrm{C}_{\mathrm{POC}}$ prior to the $P$. inermis bloom may have been driven by some diatom species in the mixed assemblage employing CCMs and/or utilising $\mathrm{HCO}_{3}^{-}$as a carbon substrate.

In summary, we find a striking relationship between diatom species composition and $\delta^{13} \mathrm{C}_{\mathrm{POC}}$ in surface waters such that large and rapid increases in abundance of $P$. inermis appear to explain the large negative shifts in surface water $\delta^{13} \mathrm{C}_{\mathrm{POC}}$. Although the exact nature of the biochemical mechanisms employed by Ryder Bay diatom species re- mains unknown, we speculate that the unusual biochemistry of $P$. inermis and its lack of a CCM during photosynthetic uptake give it a characteristically light isotopic signature. The large negative shift in surface water $\delta^{13} \mathrm{C}_{\mathrm{POC}}$ accompanying the large and rapid increase in $P$. inermis abundance can then be explained by the low $\delta^{13} C_{\mathrm{POC}}$ signature of the large proportion of diatom biomass attributable to this species.

\subsection{Factors influencing $\delta^{13} \mathrm{C}_{\mathrm{POC}}$ in sea ice}

Carbon isotopic signatures in sea ice are important because sea ice-derived organic material is released to the underlying water column during brine drainage events with implications for the sinking flux of $\delta^{13} \mathrm{C}_{\mathrm{POC}}$. Input from sea ice melting is thought to be less significant in Ryder Bay than in other coastal Antarctic environments as sea ice tends to blow out of the bay rather than undergoing extensive melting in situ (Clarke et al., 2008). However based on POC:chl $a$ and POC:PN ratios, we estimate that the maximum contribution to suspended organic carbon from sea ice material is 10 to $34 \%$ in $2004 / 05$ and 18 to $53 \%$ in $2005 / 06$. These estimates are based on minimum POC:chl $a$ of 84 for sea ice material and 22 for surface waters and minimum POC:PN of 5.35 in surface waters and 6.94 and 6.26 for sea ice in 2004/5 and $2005 / 6$ respectively. These end-member ratios were used to calculate the relative proportions of sea ice and surface water material required to produce the ratios measured in surface waters on 13 December 2004 and 23 December 2005, the two samples where sea ice material is likely to have had the strongest impact on $\delta^{13} \mathrm{C}_{\mathrm{POC}}$. Although approximate, these estimations suggest that the input of sea ice-derived organics does exert a control on surface water $\delta^{13} \mathrm{C}_{\mathrm{POC}}$ and support observations of increased surface water $\delta^{13} \mathrm{C}_{\mathrm{POC}}$ when sea ice was present in Ryder Bay.

In general, sea ice $\delta^{13} \mathrm{C}_{\mathrm{POC}}$ was enriched relative to surface waters, consistent with generally higher $\delta^{13} \mathrm{C}_{\mathrm{CO}_{2}}$, particularly in December 2005, and lower $\mathrm{CO}_{2}$ concentration in the sea ice brine (Fig. 3). This is in agreement with autotrophic carbon fixation by phytoplankton in a closed or semi-closed system and, as such, a higher degree of $\mathrm{CO}_{2}$ utilisation than in the open surface water system (Gibson et al., 1999; Villinski et al., 2000). Consequently, Ryder Bay sea ice is characterised by seasonal deficits of all major nutrients, higher dissolved oxygen concentrations and lower total alkalinity compared to surface waters (Carson, 2008). Sea ice thickness in Ryder Bay rarely exceeds $0.5 \mathrm{~m}$ (Meredith et al., 2008), so we assume that the relatively thin first year ice was undergoing some exchange with surrounding sea water. Although sea ice porosity data are not available for Ryder Bay specifically, we know that sea ice in Marguerite Bay is comparatively porous due to relatively warm conditions (Fritsen et al., 2008), ice formation through the pancake ice cycle (Eicken, 1992; Thomas and Dieckmann, 2002) and subsequent deformation and snow-ice formation (Perovich et al., 2004). Our observations agree with the expected occasional 
nutrient inputs from, and brine drainage to, surrounding sea water, and consequently less extreme environmental conditions in Ryder Bay sea ice than in more permanent sea ice environments (Gleitz et al., 1995; Kattner et al., 2004; Papadimitriou et al., 2007).

In comparison to organic carbon synthesised under closed system dynamics in multiyear ice (Papadimitriou et al., 2009), $\delta^{13} C_{\mathrm{POC}}$ values found here in $2005 / 06$ are somewhat lower, as would be expected for a semi-closed system setting. Conversely, sea ice $\delta^{13} \mathrm{C}_{\mathrm{POC}}$ in $2004 / 05$ is more ${ }^{13} \mathrm{C}$-enriched than those of Papadimitriou et al. (2009) whilst $\left[\mathrm{CO}_{2(a q)}\right]$ was lower and significantly higher POC:chl $a$ ratios compared well with values of $1262 \pm 2276$ found in intact ice floes (Kennedy et al., 2002). This suggests that 2004/05 sea ice, albeit short-lived, was closer to a closed system, but this is contested by lower $\delta^{13} \mathrm{C}_{\mathrm{CO}_{2}}$ and is not thought to be representative of prevailing sea ice conditions in Ryder Bay.

The prevailing semi-closed system dynamics at work in Ryder Bay sea ice explain higher $\delta^{13} \mathrm{C}_{\mathrm{POC}}$ than in surface waters, since photosynthesis is partially carbon-limited. We find no good correlation between $\delta^{13} \mathrm{C}_{\mathrm{POC}}$ and ambient $\left[\mathrm{CO}_{2(a q)}\right]\left(r^{2}=0.200 ; p=0.511\right.$, Fig. 8) due to occasional exchange with seawater and therefore ambient $\mathrm{CO}_{2}$ is not necessarily representative of $\mathrm{CO}_{2}$ assimilated during POC synthesis. $\delta^{13} \mathrm{C}_{\mathrm{CO}_{2}}$ is also not necessarily in equilibrium with $\delta^{13} \mathrm{C}_{\mathrm{POC}}$ sampled at the same time and may instead reflect recent replenishment of isotopically light $\mathrm{CO}_{2}$. This would explain why sea ice $\delta^{13} \mathrm{C}_{\mathrm{CO}_{2}}$ shows no response to the preferential biological uptake of ${ }^{12} \mathrm{C}$, which drives enrichment of $\delta^{13} \mathrm{C}_{\mathrm{POC}}$, and its utility for describing sea ice processes is therefore limited.

In addition to biological production, nutrient drawdown and isotopic enrichment in the semi-closed sea ice ecosystem, relatively high sea ice $\delta^{13} \mathrm{C}_{\mathrm{POC}}$ may be influenced by some species utilising $\mathrm{HCO}_{3}^{-}$as $\mathrm{CO}_{2}$ becomes limiting ( $\mathrm{Pa}-$ padimitriou et al., 2009). This would increase $\delta^{13} \mathrm{C}_{\mathrm{POC}}$ in the same way as discussed for surface waters and would impact on $\delta^{13} \mathrm{C}_{\mathrm{DIC}}$ rather than specifically $\delta^{13} \mathrm{C}_{\mathrm{CO}_{2}} \cdot \mathrm{CO}_{2}$ degassing and carbonate mineral precipitation due to $\mathrm{CO}_{2}$ saturation or supersaturation in brine inclusions upon sea ice formation may further affect $\delta^{13} \mathrm{C}_{\mathrm{CO}_{2}}$ (Romanek et al., 1992; Papadimitriou et al., 2003, 2007) and therefore $\delta^{13} \mathrm{C}_{\mathrm{POC}}$. However, low $\mathrm{CO}_{2}$ concentrations in Ryder Bay sea ice make this scenario unlikely and occasional flushing by seawater would overprint any small contribution of these processes to $\delta^{13} \mathrm{C}_{\mathrm{CO}_{2}}$.

Post-production degradation processes may also contribute to higher $\delta^{13} \mathrm{C}_{\mathrm{POC}}$ in sea ice since ${ }^{12} \mathrm{C}$ is preferentially degraded, leaving the remaining organic carbon enriched in ${ }^{13} \mathrm{C}$. This is in agreement with higher POC:chl $a$ ratios found here than in previous studies (Gosselin et al., 1990; Lizotte and Sullivan, 1992), due to additional detrital and nonalgal carbon from grazing activity and high retention (Daly, 1990; Gleitz and Thomas, 1993; Bentaleb et al., 1998). Ac- tive degradation in sea ice is also consistent with the high POC:PN ratios (Fig. 4), as organic nitrogen is preferentially degraded over carbon-bearing compounds (Rosenfeld, 1981; Hedges et al., 1986; Ganeshram et al., 1999). However, POC:PN $>10$ is common for sea ice microalgae and often implies nitrate-deprived algal metabolism (Gleitz and Thomas, 1993 and references therein), as we would expect from a semi-closed system setting. High POC:PN could also be explained by the influence of exopolymeric substances produced by diatoms and bacteria, which are abundant in the Antarctic marine environment, especially in sea ice (Meiners et al., 2004; Mancuso Nichols et al., 2005), and so may not be diagnostic of post-production degradation alone. We cannot use $\delta^{13} \mathrm{C}_{\mathrm{CO}_{2}}$ to confirm whether in situ degradation is an important influence on sea ice $\delta^{13} \mathrm{C}_{\mathrm{POC}}$, because the aforementioned exchange with isotopically light seawater $\mathrm{CO}_{2}$ would mask any $\delta^{13} \mathrm{C}_{\mathrm{CO}_{2}}$ depletion that would accompany preferential degradation of organic ${ }^{12} \mathrm{C}$. Proboscia species were found in only one sea ice sample, but abundance was negligible, therefore we observe no $P$. inermis control on sea ice $\delta^{13} \mathrm{C}_{\mathrm{POC}}$ such as we demonstrate in surface waters. However, unlike surface waters, least-squares linear regression analysis of sea ice brine samples shows a good relationship between SA:V and $\delta^{13} \mathrm{C}_{\mathrm{POC}}\left(r^{2}=0.713, p=0.101, n=4\right.$; Fig. 9), which becomes statistically significant when we include early season surface water samples thought to be dominated by sea ice material $\left(r^{2}=0.761, p=0.0146, n=6\right)$. However, given the difference in $\delta^{13} \mathrm{C}_{\mathrm{POC}}$ between sea ice and water samples with similar SA:V ratios, as well as different $\mathrm{SA}: \mathrm{V}$ in sea ice versus water samples with similar $\delta^{13} \mathrm{C}_{\mathrm{POC}}$ values, the effect of diatom SA: $\mathrm{V}$ on $\varepsilon_{p}$ alone is unable to account for higher $\delta^{13} \mathrm{C}_{\mathrm{POC}}$ in sea ice than surface waters.

In summary, higher $\delta^{13} \mathrm{C}_{\mathrm{POC}}$ in sea ice than surface waters is likely attributable to a higher degree of $\mathrm{CO}_{2}$ utilisation due to the semi-closed nature of the sea ice ecosystem. Postproduction degradation of organic material, direct $\mathrm{HCO}_{3}^{-}$uptake by some sea ice diatoms and possible production of exopolymeric substances may further contribute to isotopically heavy sea ice-derived organic material.

\subsection{Sinking particulate organic carbon}

Sinking particulate $\delta^{13} \mathrm{C}_{\mathrm{POC}}$ time-series data (Fig. 7) show similar features to the surface water time-series (Fig. 3), suggesting that although $P$. inermis was not dominant in sediment traps, the associated $\delta^{13} \mathrm{C}_{\mathrm{POC}}$ signatures produced in surface waters are transferred to depth. Down-depth trends in seasonal average $\delta^{13} \mathrm{C}_{\mathrm{POC}}$ through the water column to sediment core-top material (Fig. 11) show that Ryder Bay sinking particulate matter is more depleted in $\delta^{13} \mathrm{C}_{\mathrm{POC}}$ in 2005/06 than 2004/05, consistent with much lower seasonaverage surface water $\delta^{13} \mathrm{C}_{\mathrm{POC}}$ in $2005 / 06$ ( $-24.5 \%$ vs. $20.0 \%$ ). This is in response to the large and prolonged lateseason negative $\delta^{13} \mathrm{C}_{\mathrm{POC}}$ shift, which is observed in both the 


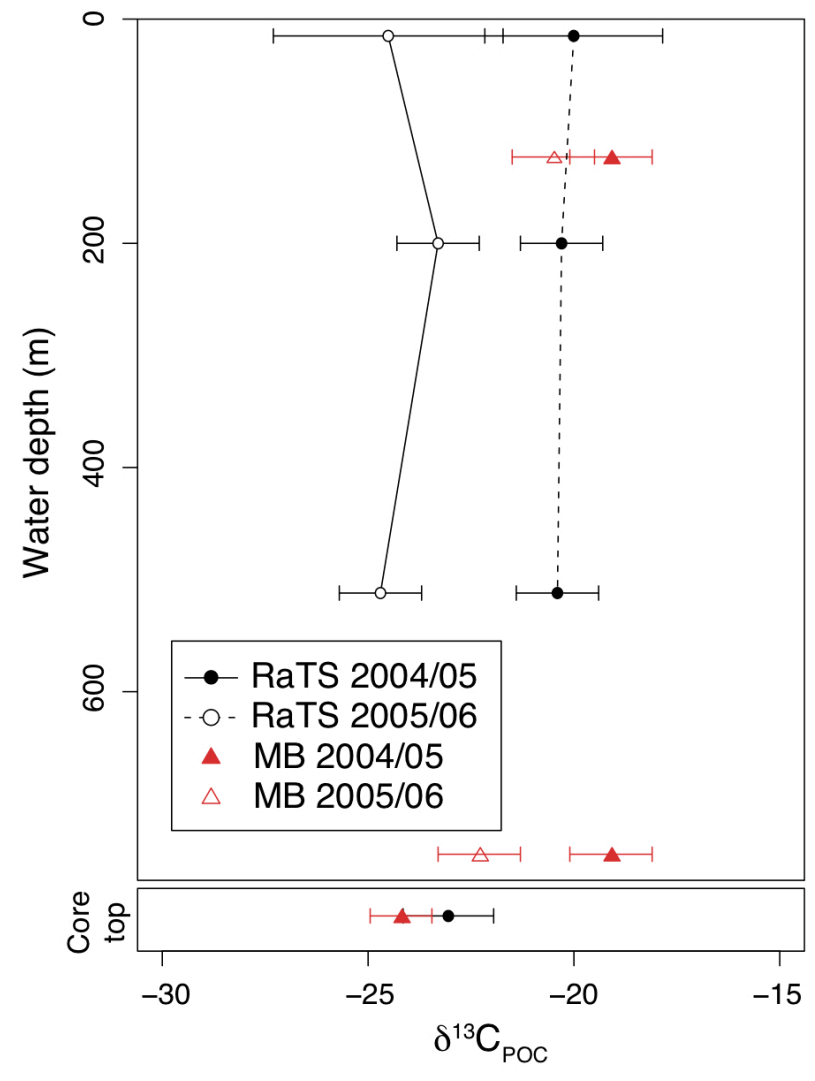

Fig. 11. Depth profiles of seasonal average $\delta^{13} \mathrm{C}_{\mathrm{POC}}$ in Ryder Bay (RaTS; circles) and Marguerite Bay (MB; triangles) for 2004/05 (filled symbols) and 2005/06 (open symbols). The uppermost point in each Ryder Bay profile is the seasonal concentration-weighted average suspended particle $\delta^{13} \mathrm{C}_{\mathrm{POC}}$ value from surface water samples, with error bars representing $1^{*} \sigma$. All other points in the upper panel represent seasonal flux-weighted average $\delta^{13} \mathrm{C}_{\mathrm{POC}}$ in sediment traps, with errors of $1.0 \%$ associated with formaldehyde preservation (Mincks et al., 2008) as this vastly exceeds analytical error. The lower panel shows $\delta^{13} \mathrm{C}_{\mathrm{POC}}$ of core-top sediments. Error bars for Ryder Bay core-top $\delta^{13} \mathrm{C}_{\mathrm{POC}}$ represents $1 * \sigma$. For Marguerite Bay core-top, error bars represent analytical error of $0.75 \%$.

$200 \mathrm{~m}$ and $512 \mathrm{~m}$ sediment traps, albeit approximately one month later (Fig. 7). Although Marguerite Bay sediment trap $\delta^{13} C_{\mathrm{POC}}$ is also lower in $2005 / 06$ than $2004 / 05$, the signal is much more pronounced in Ryder Bay, suggesting that low $\delta^{13} \mathrm{C}_{\mathrm{POC}}$ related to $P$. inermis dominance is a localised phenomenon.

Sinking $\delta^{13} \mathrm{C}_{\mathrm{POC}}$ is always higher in Marguerite Bay than Ryder Bay at any given time. However, within each season at both sites, $\delta^{13} \mathrm{C}_{\mathrm{POC}}$ in the deepest trap is within $0.4 \%$ of its surface water (Ryder Bay) or shallow trap (Marguerite Bay) counterpart. The only exception is Marguerite Bay in $2005 / 06$, where shallow and deep trap values fall within $2 \%$. This clear relationship between $\delta^{13} \mathrm{C}_{\mathrm{POC}}$ in surface waters and sediment traps provides evidence that surface ocean $\delta^{13} \mathrm{C}_{\mathrm{POC}}$ signatures are faithfully exported to depth in the water column, even despite the loss of key diatom species during sinking.

Sediment core-top $\delta^{13} \mathrm{C}_{\mathrm{POC}}$ in Ryder Bay is slightly higher than in the deepest sediment trap (Fig. 11), likely because of minor sedimentary remineralisation or due to the fact that surface sediments integrate $\delta^{13} \mathrm{C}_{\mathrm{POC}}$ signatures over longer time scales. However, enrichment of core-top $\delta^{13} \mathrm{C}_{\mathrm{POC}}$ relative to deep trap $\delta^{13} \mathrm{C}_{\mathrm{POC}}$ is close to error and so we suggest that $\delta^{13} \mathrm{C}_{\mathrm{POC}}$ of sinking particles is reliably transferred to marine sediments.

\subsection{Potential implications for $\delta^{13} C_{P O C}$ in Southern Ocean sediments as a paleoceanographic proxy}

Results presented in this study hold important implications for the use of sedimentary $\delta^{13} \mathrm{C}_{\mathrm{POC}}$ as a proxy for past environmental conditions in the coastal Southern Ocean. Marine sedimentary records show glacial Southern Ocean $\delta^{13} \mathrm{C}_{\mathrm{POC}}$ to be approximately $4 \%$ o depleted relative to interglacial epochs (Singer and Shemesh, 1995; Rosenthal et al., 2000; Crosta and Shemesh, 2002; Schneider-Mor et al., 2005). Traditionally, low glacial $\delta^{13} \mathrm{C}_{\mathrm{POC}}$ was explained by higher $\left[\mathrm{CO}_{2(a q)}\right]$ due to strengthening of the thermohaline circulation and wide-spread enhanced upwelling (Rau et al., 1992; Singer and Shemesh, 1995). However, later studies contradict this upwelling theory by using other proxy records such as $\delta^{15} \mathrm{~N}_{\text {org }} \& \mathrm{Ba} / \mathrm{Al}$ to infer a stratified glacial Southern Ocean and reduced productivity (François et al., 1997). The anti-correlation of low glacial $\delta^{13} \mathrm{C}_{\mathrm{POC}}$ and high glacial $\delta^{15} \mathrm{~N}_{\text {org }}$ can be reconciled by increased stratification restricting nitrate supply and increasing $\delta^{15} \mathrm{~N}_{\text {org }}$ and sea ice cover preventing ocean-atmosphere gas exchange so that $\left[\mathrm{CO}_{2(a q)}\right]$ remains high and $\delta^{13} \mathrm{C}_{\mathrm{POC}}$ low (Crosta and Shemesh, 2002).

We have shown that seasonal changes in diatom assemblages can drive short-lived yet large isotopic transitions in coastal Antarctic surface waters and have a profound impact on seasonal average $\delta^{13} \mathrm{C}_{\mathrm{POC}}$ exported to depth and underlying sediments. Most importantly, seasonal average $\delta^{13} \mathrm{C}_{\mathrm{POC}}$ for a season of well-mixed conditions is $4 \%$ higher than a much more stratified season preceded by a heavy sea ice winter, such as may have been typical of glacial times. The $4 \%$ difference matches the full amplitude of the glacialinterglacial offset in $\delta^{13} \mathrm{C}_{\mathrm{POC}}$ from Southern Ocean sediment cores.

We hypothesise therefore that diatom species shifts may be an important driver of lower glacial $\delta^{13} \mathrm{C}_{\mathrm{POC}}$ in the Southern Ocean, in agreement with Jacot Des Combes et al. (2008). Whilst it is $P$. inermis that appears to be driving large isotopic shifts in this study, we do not specifically invoke this species as a driver of $\delta^{13} \mathrm{C}_{\mathrm{POC}}$ over glacial-interglacial cycles. Other diatom species employing similar unusual biochemistry may be important contributors to low glacial $\delta^{13} \mathrm{C}_{\mathrm{POC}}$. Although sedimentary diatom assemblages do not show such drastic changes as witnessed in this study (Gersonde and Zielinski, 2000; Bianchi and Gersonde, 2004) and 
there is no evidence for significant changes in Proboscia species in the open ocean on glacial-interglacial timescales (Crosta et al., 2004), this does not preclude a species control on low glacial $\delta^{13} \mathrm{C}_{\mathrm{POC}}$. Instead, the species responsible for low glacial $\delta^{13} \mathrm{C}_{\mathrm{POC}}$ may not be well preserved in sediments, whilst its isotopic signature is preserved, as is demonstrated here for P. inermis.

With these caveats in mind, we demonstrate that changes in surface water diatom assemblages can drive shifts in seasonal average $\delta^{13} \mathrm{C}_{\mathrm{POC}}$ of equal amplitude to the $4 \%$ glacialinterglacial $\delta^{13} \mathrm{C}_{\mathrm{POC}}$ offset observed in marine sedimentary records. We show that these surface water isotopic shifts are transferred to marine sediments and we propose therefore that at least part of the lower glacial $\delta^{13} \mathrm{C}_{\mathrm{POC}}$ signal may be due to changes in diatom assemblages. If the more glacialtype conditions of heavier winter sea ice and upper water stratification in 2005/06 were responsible for driving a shift to diatom species characterised by lower isotopic signatures, in this case P. inermis, then it follows that species compositional shifts may be a significant influence on $\delta^{13} \mathrm{C}_{\mathrm{POC}}$ on glacial-interglacial timescales. Further studies are required to elucidate the processes underlying this relationship.

\section{Conclusions}

This study presents a unique insight into the factors affecting $\delta^{13} \mathrm{C}_{\mathrm{POC}}$ in the coastal Antarctic sea ice environment. In agreement with previous studies, we find higher $\delta^{13} \mathrm{C}_{\mathrm{POC}}$ in sea ice brine relative to surface waters, consistent with autotrophic carbon fixation in a semi-closed environment. Possible secondary effects on sea ice $\delta^{13} \mathrm{C}_{\mathrm{POC}}$ may result from biological utilisation of $\mathrm{HCO}_{3}^{-}$in addition to $\mathrm{CO}_{2}$ as a carbon substrate, production of exopolymeric substances and/or post-production degradation of organic matter within the ice matrix. Sea ice-derived organics exert a short-lived impact on surface water $\delta^{13} \mathrm{C}_{\mathrm{POC}}$ in Ryder Bay due to brine drainage processes whilst sea ice is present. Isotopically heavy sea ice material tends to sink quickly, so may be preserved more effectively in the sedimentary record and may consequently bias the overall $\delta^{13} \mathrm{C}_{\mathrm{POC}}$ signal in marine sediments.
We demonstrate that $\left[\mathrm{CO}_{2(a q)}\right]$ and $\delta{ }^{13} \mathrm{C}_{\mathrm{CO}_{2}}$ are not the primary factors controlling variations in $\delta^{13} \mathrm{C}_{\mathrm{POC}}$ in surface waters in the Antarctic sea ice environment. Instead, we argue that $\sim 10 \%$ negative excursions in surface water $\delta^{13} \mathrm{C}_{\mathrm{POC}}$ are driven by seasonal shifts in diatom assemblages, in this case specifically to dominance of $P$. inermis. While the exact mechanisms remain unknown, we postulate that $P$. inermis may modify $\delta^{13} \mathrm{C}_{\mathrm{POC}}$ through its internal cell biochemistry and lack of a CCM, whilst other species present at different times in the growing seasons do employ CCMs. Consequently, seasonal species-related changes in $\varepsilon_{p}$ further complicate the relationship between $\delta^{13} \mathrm{C}_{\mathrm{POC}}$ and $\left[\mathrm{CO}_{2(a q)}\right]$.

Finally, sediment trap data indicate that although much of the surface suspended material, including certain diatom species, undergoes recycling in the upper ocean and is not exported to depth, the $\delta^{13} \mathrm{C}_{\mathrm{POC}}$ signal is transferred to depth in the water column by sinking particles. Further, we show how isotopic signatures in these sinking particles are transferred to marine sediments unaltered. This study therefore identifies the importance of seasonal changes in surface water diatom speciation and isotopically heavy sea ice-derived material for $\delta^{13} \mathrm{C}_{\mathrm{POC}}$ signatures in Antarctic coastal environments and underlying sediments, and thus highlights the need for analysis of species-specific or diatom-bound $\delta^{13} \mathrm{C}_{\mathrm{POC}}$ in order to reliably interpret sedimentary $\delta^{13} \mathrm{C}$ records. 
Table A1. Type, input terms and results of statistical analyses performed using R computing software. All regressions are least-squares linear regressions and $r^{2}$ values are given as the adjusted $r^{2}$.

\begin{tabular}{|c|c|c|c|c|c|}
\hline Type of analysis & Independent variable & $\begin{array}{l}\text { Dependent } \\
\text { variable }\end{array}$ & Samples & $r^{2}$ & $p$-value \\
\hline Correlation & {$\left[\mathrm{CO}_{2(a q)}\right]$} & $\delta^{13} \mathrm{C}_{\mathrm{POC}}$ & Seawater & 0.247 & 0.120 \\
\hline Correlation & {$\left[\mathrm{CO}_{2(a q)}\right]$} & $\delta^{13} \mathrm{C}_{\mathrm{POC}}$ & Sea ice & 0.200 & 0.511 \\
\hline Regression & $\mathrm{SA}: \mathrm{V}$ & $\delta^{13} \mathrm{C}_{\mathrm{POC}}$ & Seawater & 0.472 & 0.017 \\
\hline Regression & $\%$ P. inermis & $\delta^{13} \mathrm{C}_{\mathrm{POC}}$ & $\begin{array}{l}\text { Seawater } \\
\text { 2005/6 only }\end{array}$ & 0.968 & 0.000243 \\
\hline Regression & $\%$ P. inermis & $\delta^{13} \mathrm{C}_{\mathrm{POC}}$ & $\begin{array}{l}\text { Seawater } \\
>2 \% \text { P. inermis }\end{array}$ & 0.918 & 0.000423 \\
\hline Regression & \% Proboscia spp. & $\delta^{13} \mathrm{C}_{\mathrm{POC}}$ & $\begin{array}{l}\text { Seawater } \\
>2 \% \text { Proboscia } \text { spp. }\end{array}$ & 0.922 & 0.00037 \\
\hline Regression & SA:V & $\delta^{13} \mathrm{C}_{\mathrm{POC}}$ & Sea ice & 0.713 & 0.101 \\
\hline Regression & SA:V & $\delta^{13} \mathrm{C}_{\mathrm{POC}}$ & Sea ice and ice-influenced & 0.761 & 0.0146 \\
\hline
\end{tabular}

Acknowledgements. The authors would like to thank two anonymous reviewers for constructive comments and helpful feedback. This work was funded by NERC (NER/S/S/2004/12773) and the Commonwealth Scholarships and Fellowships Programme. This study is part of the ESF PolarClimate HOLOCLIP Project (HOLOCLIP publication no. 7). SUERC was supported by the Universities of the Scottish Consortium and the SHEFC programme SAGES. The authors gratefully acknowledge the marine science team based at Rothera Research Station (2004-06), officers, crew and scientists of the R.R.S. James Clark Ross (2004-06), Colin Chilcott for assistance with $\delta^{13} \mathrm{C}$ analysis and Nicola Cayzer for assistance with SEM analysis.

Edited by: S. Pantoja

\section{References}

Almgren, T., Dyrssen, D., and Fonselius, S.: Determination of alkalinity and total carbonate, in: Methods of Seawater Analysis, 2, edited by: Grasshoff, K., Ehrhardt, M., and Kremling, K., Verlag-Chemie, Weinheim, Germany, 99-123, 1983.

Altabet, M. A.: Nitrogen isotopic evidence for micronutrient control of fractional $\mathrm{NO}_{3}^{-}$utilization in the equatorial Pacific, Limnol. Oceanogr., 46, 368-380, 2001.

Annett, A. L., Carson, D. S., Crosta, X., Clarke, A., and Ganeshram, R. S.: Seasonal progression of diatom assemblages in surface waters of Ryder Bay, Antarctica, Polar Biology, 33, 13-29, 2010.

Assayag, N., Rivé, K., Ader, M., Jézéquel, D., and Agrinier, P.: Improved method for isotopic and quantitative analysis of dissolved inorganic carbon in natural water samples, Rapid Commun. Mass Spectrom., 20, 2243-2251, 2006.

Barnola, J. M., Raynaud, D., Korotkevich, Y. S., and Lorius, C.: Vostok ice core provides 160,000-year record of atmospheric $\mathrm{CO}_{2}$, Nature, 329, 408-414, 1987.

Barth, J. A., Cowles, T. J., and Pierce, S. D.: Mesoscale physical and bio-optical structure of the Antarctic Polar Front near $170^{\circ} \mathrm{W}$ during austral spring, J. Geophys. Res., 106, 1387913902, 2001.

Bentaleb, I. and Fontugne, M.: The role of the southern Indian Ocean in the glacial to interglacial atmospheric $\mathrm{CO}_{2}$ change: organic carbon isotope evidences. Global Planet. Change, 16-17, 25-36, 1998.

Bentaleb, I., Fontugne, M., Descolas-Gros, C., Girardin, C., Mariotti, A., Pierre, C., Brunet, C., and Poisson, A.: Carbon isotopic fractionation by plankton in the Southern Indian Ocean: relationship between $\delta^{13} \mathrm{C}$ of particulate organic carbon and dissolved carbon dioxide, J. Mar. Syst., 17, 39-58, 1998.

Berner, W., Oeschger, H., and Stauffer, B.: Information on the $\mathrm{CO}_{2}$ cycle from ice core studies, Radiocarbon, 22, 227-235, 1980.

Bianchi, C. and Gersonde, R.: Climate evolution at the last deglaciation: The role of the Southern Ocean, Earth Planet. Sci. Lett., 228, 407-424, 2004.

Burkhardt, S., Riebesell, U., and Zondervan, I.: Effects of growth rate, $\mathrm{CO}_{2}$ concentration, and cell size on the stable carbon isotope fractionation in marine phytoplankton, Geochim. Cosmochim. Acta, 63, 3729-3741, 1999.

Carson, D. S.: Biogeochemical controls on productivity and particle flux in the coastal Antarctic sea ice environment, Ph.D. thesis, University of Edinburgh, UK, 205 pp., 2008.

Cassar, N., Laws, E. A., and Bidigare, R. R.: Bicarbonate uptake by Southern Ocean phytoplankton, Global Biogeochem. Cycles, 18, GB2003, doi:2010.1029/2003GB002116, 2004.

Clarke, A., Meredith, M. P., Wallace, M. I., Brandon, M. A., and Thomas, D. N.: Seasonal and interannual variability in temperature, chlorophyll and macronutrients in northern Marguerite Bay, Antarctica, Deep Sea Res. Pt. II, 55, 1988-2006, 2008.

Crosta, X. and Shemesh, A.: Reconciling down core anticorrelation of diatom carbon and nitrogen isotopic ratios from the Southern Ocean, Paleoceanography, 17, 1010, doi:10.1029/2000PA000565, 2002.

Crosta, X., Sturm, A., Armand, L., and Pichon, J.-J.: Late Quaternary sea ice history in the Indian sector of the Southern Ocean as recorded by diatom assemblages, Mar. Micropaleontol., 50, 209-223, doi:10.1016/S0377-8398(03)00072-0, 2004.

Crosta, X., Crespin, J., Billy, I., and Ther, O.: Major factors con- 
trolling Holocene $\delta^{13} \mathrm{C}_{\text {org }}$ changes in a seasonal sea-ice environment, Adélie Land, East Antarctica, Global Biogeochem. Cycles, 19, GB4029, doi:10.1029/2004GB002426, 2005.

Daly, K. L.: Overwintering development, growth, and feeding of larval Euphausia superba in the Antarctic marginal ice zone, Limnol. Oceanogr., 35, 1564-1576, 1990.

Deines, P., Langmuir, D., and Harmon, R. S.: Stable carbon isotope ratios and the existence of a gas phase in the evolution of carbonate ground waters, Geochim. Cosmochim. Acta, 38, 1147-1164, 1974.

Descolas-Gros, C. and Fontugne, M. R.: Carbon fixation in marine phytoplankton: carboxylase activities and stable carbonisotope ratios; physiological and palaeoclimatological aspects, Mar. Biol., 87, 1-6, 1985.

Dickson, A. G. and Millero, F. J.: A comparison of the equilibrium constants for the dissociation of carbonic acid in seawater media, Deep Sea Res. Pt. I, 34, 1733-1743, 1987.

Eicken, H.: The role of sea ice in structuring Antarctic ecosystems, Polar Biology, 12, 3-13, 1992.

Eppley, R. W., Renger, E. H., Venrick, E. L., and Mullin, M. M.: A study of plankton dynamics and nutrient cycling in the central gyre of the North Pacific Ocean, Limnol. Oceanogr., 18, 534551, 1973.

Falkowski, P. G.: Species variability in the fractionation of ${ }^{13} \mathrm{C}$ and ${ }^{12} \mathrm{C}$ by marine phytoplankton, J. Plankton Res., 13, 21-28, 1991.

Fontugne, M. R., Descolas-Gros, C., and de Billy, G.: The dynamics of $\mathrm{CO}_{2}$ fixation in the Southern Ocean as indicated by carboxylase activities and organic carbon isotopic ratios, Mar. Chem., 35, 371-380, 1991.

François, R., Altabet, M. A., Goericke, R., McCorkle, D. C., Brunet, C., and Poisson, A.: Changes in the $\delta^{13} \mathrm{C}$ of surface water particulate organic matter across the subtropical convergence in the S.W. Indian Ocean, Global Biogeochem. Cycles, 7, 627644, 1993.

François, R., Altabet, M. A., Yu, E.-F., Sigman, D. M., Bacon, M. P., Frank, M., Bohrmann, G., Bareille, G., and Labeyrie, L. D.: Contribution of Southern Ocean surface-water stratification to low atmospheric $\mathrm{CO}_{2}$ concentrations during the last glacial period, Nature, 389, 929-935, 1997.

Freeman, K. H. and Hayes, J. M.: Fractionation of carbon isotopes by phytoplankton and estimates of ancient $\mathrm{CO}_{2}$ levels, Global Biogeochem. Cycles, 6, 185-198, 1992.

Fritsen, C. H., Memmott, J., and Stewart, F. J.: Inter-annual sea-ice dynamics and micro-algal biomass in winter pack ice of Marguerite Bay, Antarctica, Deep Sea Res. Part II, 55, 2059-2067, 2008.

Ganeshram, R. S., Calvert, S. E., Pedersen, T. F., and Cowie, G. L.: Factors controlling the burial of organic carbon in laminated and bioturbated sediments off NW Mexico: Implications for hydrocarbon preservation, Geochim. Cosmochim. Acta, 63, 17231734, 1999.

Garibotti, I. A., Vernet, M., and Ferrario, M. E.: Annually recurrent phytoplanktonic assemblages during summer in the seasonal ice zone west of the Antarctic Peninsula (Southern Ocean), Deep Sea Res. Part I, 52, 1823-1841, 2005.

Gersonde, R. and Zielinski, U.: Reconstruction of Late Quaternary Antarctic sea-ice distribution - The use of diatoms as a proxy for sea ice, Palaeogeogr., Palaeoclimatol., Palaeoecol., 162, 263286, 2000.
Gibson, J. A. E., Trull, T., Nichols, P. D., Summons, R. E., and McMinn, A.: Sedimentation of ${ }^{13} \mathrm{C}$-rich organic matter from Antarctic sea-ice algae: A potential indicator of past sea-ice extent, Geology, 27, 331-334, 1999.

Gleitz, M. and Thomas, D. N.: Variation in phytoplankton standing stock, chemical composition and physiology during sea-ice formation in the southeastern Weddell Sea, Antarctica, J. Exp. Mar. Biol. Ecol., 173, 211-230, 1993.

Gleitz, M., Rutgers v.d. Loeff, M., Thomas, D. N., Dieckmann, G. S., and Millero, F. J.: Comparison of summer and winter inorganic carbon, oxygen and nutrient concentrations in Antarctic sea ice brine, Mar. Chem., 51, 81-91, 1995.

Goericke, R., Montoya, J. P., and Fry, B.: Physiology of isotopic fractionation in algae and cyanobacteria, in: Stable Isotopes in Ecology and Environmental Science, edited by: Lajtha, K. and Michener, R. H., Blackwell Scientific Publications, Oxford, UK, 187-221, 1994.

Gosselin, M., Legendre, L., Therriault, J.-C., and Demers, S.: Light and nutrient limitation of sea-ice microalgae (Hudson Bay, Canadian Arctic), J. Phycol., 26, 220-232, doi:10.1111/j.00223646.1990.00220.x, 1990.

Guy, R. D., Vanlerberghe, G. C., and Turpin, D. H.: Significance of phosphoenolpyruvate carboxylase during ammonium assimilation: Carbon isotope discrimination in photosynthesis and respiration by the N-limited green alga Selenastrum minutum, Plant Physiol., 89, 1150-1157, 1989.

Hannson, I.: A new set of activity constants for carbonic acid and boric acid in seawater, Deep Sea Res., 20, 461-478, 1973.

Hayes, J. M.: Factors controlling ${ }^{13} \mathrm{C}$ contents of sedimentary organic compounds: principles and evidence, Mar. Geol., 113, 111-125, 1993.

Hedges, J. I., Clark, W. A., Quay, P. D., Richey, J. E., Devol, A. H., and Santos, U. D.: Compositions and fluxes of particulate matter in the Amazon River, Limnol. Oceanogr., 31, 717-738, 1986.

Jacot Des Combes, H., Esper, O., De La Rocha, C.L., Abelmann, A., Gersonde, R., Yam, R., and Shemesh, A.: Diatom $\delta^{13} \mathrm{C}, \delta^{15} \mathrm{~N}$ and $\mathrm{C} / \mathrm{N}$ since the Last Glacial Maximum in the Southern Ocean: Potential impact of species composition, Paleoceanography, 23, PA4209, doi:10.1029/2008PA001589, 2008.

Jasper, J. P. and Hayes, J. M.: A carbon-isotopic record of $\mathrm{CO}_{2}$ levels during the Late Quaternary, Nature, 347, 462-464, 1990.

Jasper, J. P., Hayes, J. M., Mix, A. C., and Prahl, F. G.: Photosynthetic fractionation of ${ }^{13} \mathrm{C}$ and concentrations of dissolved $\mathrm{CO}_{2}$ in the central equatorial Pacific during the last 255,000 years, Paleoceanography, 9, 781-798, 1994.

Kattner, G., Thomas, D. N., Haas, C., Kennedy, H., and Dieckmann, G. S.: Surface ice and gap layers in Antarctic sea ice: highly productive habitats, Mar. Ecol. Prog. Ser., 277, 1-12, 2004.

Kennedy, H., Thomas, D. N., Kattner, G., Haas, C., and Dieckmann, G. S.: Particulate organic matter in Antarctic summer sea ice: concentration and stable isotopic composition, Mar. Ecol. Prog. Ser., 238, 1-13, 2002.

Kerby, N. W. and Raven, J. A.: Transport and fixation of inorganic carbon by marine algae, Advances in Botanical Research, 11, 71-123, 1985.

Laws, E. A., Popp, B. N., Bidigare, R. R., Kennicutt, M. C., and Macko, S. A.: Dependence of phytoplankton carbon isotopic composition on growth rate and $\left[\mathrm{CO}_{2}\right]_{a q}$ : Theoretical considerations and experimental results, Geochim. Cosmochim. Acta, 
59, 1131-1138, 1995.

Laws, R. A.: Preparing strewn slides for quantitative microscopical analysis: A test using calibrated microspheres, Micropaleontology, 29 , 60-65, 1983.

Le Roux-Swarthout, D., Terwilliger, V., Christianson, M., Martin, C., and Mardhavan, S.: Carbon isotope discrimination correlates with a range of ratios of phosphoenolpyruvate to total carboxylase activities found in two $\mathrm{C}_{3}$ species, J. Plant Physiol., 157, 489-493, 2000.

Lewis, E. and Wallace, D. W. R.: CO2SYS, version 01.05, Program developed for $\mathrm{CO}_{2}$ system calculations. ORNL/CDIAC105. Carbon dioxide information analysis center, Oak Ridge National Laboratory, U.S. Department of Energy, Oak Ridge, Tennessee, 1998.

Lizotte, M. P. and Sullivan, C. W.: Biochemical composition and photosynthate distribution in sea ice microalgae of McMurdo Sound, Antarctica: evidence for nutrient stress during the spring bloom, Antarct. Sci., 4, 23-30, 1992.

Lourey, M. J., Trull, T. W., and Tilbrook, B.: Sensitivity of $\delta^{13} \mathrm{C}$ of Southern Ocean suspended and sinking organic matter to temperature, nutrient utilization, and atmospheric $\mathrm{CO}_{2}$, Deep Sea Res. Pt. I, 51, 281-305, 2004.

Mancuso Nichols, C. A., Guezennec, J., and Bowman, J. P.: Bacterial exopolysaccharides from extreme marine environments with special consideration of the Southern Ocean, sea ice, and deepsea hydrothermal vents: A review, Mar. Biotechnol., 7, 253-271, 2005.

Masson-Delmotte, V., Stenni, B., Pol, K., Braconnot, P., Cattani, O., Falourd, S., Kageyama, M., Jouzel, J., Landais, A., Minster, B., Barnola, J.M., Chappellaz, J., Krinner, G., Johnsen, S., Röthlisberger, R., Hansen, J., Mikolajewicz, U., and OttoBliesner, B.: EPICA Dome C record of glacial and interglacial intensities, Quat. Sci. Rev., 29, 113-128, 2010.

Mehrbach, C., Culberson, C. H., Hawley, J. E., and Pytkowicz, R. M.: Measurement of the apparent dissociation constants of carbonic acid in seawater at atmospheric pressure, Limnol. Oceanogr., 18, 897-907, 1973.

Meiners, K., Brinkmeyer, R., Granskog, M. A., and Lindfors, A.: Abundance, size distribution and bacterial colonization of exopolymer particles in Antarctic sea ice (Bellingshausen Sea), Aquat. Microb. Ecol., 35, 283-296, 2004.

Meredith, M. P., Renfrew, I. A., Clarke, A., King, J. C., and Brandon, M. A.: Impact of the 1997/98 ENSO on upper ocean characteristics in Marguerite Bay, western Antarctic Peninsula, J. Geophys. Res., 109, C09013, doi:10.1029/2003JC001784, 2004.

Meredith, M. P., Brandon, M. A., Wallace, M. I., Clarke, A., Leng, M. J., Renfrew, I. A., van Lipzig, N. P. M., and King, J. C.: Variability in the freshwater balance of northern Marguerite Bay, Antarctic Peninsula: results from $\delta^{18}$ O, Deep Sea Res. Pt. II, 55, 309-322, 2008.

Mincks, S. L., Smith, C. R., Jeffreys, R. M., and Sumida, P. Y. G.: Trophic structure on the West Antarctic Peninsula shelf: Detritivory and benthic inertia revealed by $\delta^{13} \mathrm{C}$ and $\delta^{15} \mathrm{~N}$ analysis, Deep Sea Res. Pt. II, 55, 2502-2514, 2008.

Mook, W. G., Bommerson, J. C., and Staverman, W. H.: Carbon isotope fractionation between dissolved bicarbonate and gaseous carbon dioxide, Earth Planet. Sci. Lett., 22, 169-176, 1974.

O'Leary, M. H.: Carbon-isotope fractionation in plants, Phytochemistry, 20, 553-567, 1981.
O'Leary, M. H., Madhavan, S., and Paneth, P.: Physical and chemical basis of carbon isotope fractionation in plants, Plant, Cell and Environment, 15, 1099-1104, 1992.

O'Leary, T., Trull, T. W., Griffiths, F. B., Tilbrook, B., and Revill, A. T.: Euphotic zone variations in bulk and compound-specific $\delta^{13} \mathrm{C}$ of suspended organic matter in the subantarctic ocean, south of Australia, J. Geophys. Res. C: Oceans, 106, 31669-31684, doi:10.1029/2000JC000288, 2001.

Papadimitriou, S., Kennedy, H., Kattner, G., Dieckmann, G. S., and Thomas, D. N.: Experimental evidence for carbonate precipitation and $\mathrm{CO}_{2}$ degassing during sea ice formation, Geochim. Cosmochim. Acta, 68, 1749-1761, 2003.

Papadimitriou, S., Thomas, D. N., Kennedy, H., Haas, C., Kuosa, H., Krell, A., and Dieckmann, G. S.: Biogeochemical composition of natural sea ice brines from the Weddell Sea during early austral summer, Limnol. Oceanogr., 52, 1809-1823, 2007.

Papadimitriou, S., Thomas, D. N., Kennedy, H., Kuosa, H., and Dieckmann, G. S.: Inorganic carbon removal and isotopic enrichment in Antarctic sea ice gap layers during early austral summer, Mar. Ecol. Prog. Ser., 386, 15-27, doi:10.3354/meps08049, 2009.

Perovich, D. K., Elder, B. C., Claffey, K. J., Stammerjohn, S., Smith, R., Ackley, S. F., Krouse, H. R., and Gow, A. J.: Winter sea-ice properties in Marguerite Bay, Antarctica, Deep Sea Res. Pt. II, 51, 2023-2039, 2004.

Pollehne, F., Klein, B., and Zeitzschel, B.: Low light adaptation and export production in the deep chlorophyll maximum layer in the northern Indian Ocean, Deep Sea Res. Pt. II, 40, 737-752, 1993.

Popp, B. N., Laws, E. A., Bidigare, R. R., Dore, J. E., Hanson, K. L., and Wakeham, S. G.: Effect of phytoplankton cell geometry on carbon isotopic fractionation, Geochim. Cosmochim. Acta, 62, 69-77, doi:10.1016/S0016-7037(97)00333-5, 1998.

Popp, B. N., Trull, T., Kenig, F., Wakeham, S. G., Rust, T. M., Tilbrook, B., Griffiths, F. B., Wright, S. W., Marchant, H. J., Bidigare, R. R., and Laws, E. A.: Controls on the carbon isotopic composition of Southern Ocean phytoplankton, Global Biogeochem. Cycles, 13, 827-844, 1999.

Rau, G. H.: Plankton ${ }^{13} \mathrm{C} /{ }^{12} \mathrm{C}$ variations in Monterey Bay, California: evidence of non-diffusive inorganic carbon uptake by phytoplankton in an upwelling environment, Deep Sea Res. Pt. I, 48, 79-94, 2001.

Rau, G. H., Takahashi, T., and Des Marais, D. J.: Latitudinal variations in plankton $\delta^{13} \mathrm{C}$ : implications for $\mathrm{CO}_{2}$ and productivity in past oceans, Nature, 341, 516-518, 1989.

Rau, G. H., Froelich, P. N., Takahashi, T., and Des Marais, D. J.: Does sedimentary organic $\delta^{13} \mathrm{C}$ record variations in Quaternary ocean $\left[\mathrm{CO}_{2(a q)}\right]$ ? Paleoceanography, 6, 335-347, 1991.

Rau, G. H., Takahashi, T., Des Marais, D. J., Repeta, D. J., and Martin, J. H.: The relationship between $\delta^{13} \mathrm{C}$ of organic matter and $\left[\mathrm{CO}_{2(a q)}\right]$ in ocean surface water: data from a JGOFS site in the northeast Atlantic Ocean and a model, Geochim. Cosmochim. Acta, 56, 1413-1419, 1992.

Rau, G. H., Riebesell, U., and Wolf-Gladrow, D.: A model of photosynthetic ${ }^{13} \mathrm{C}$ fractionation by marine phytoplankton based on diffusive molecular $\mathrm{CO}_{2}$ uptake, Mar. Ecol. Prog. Ser., 133, 275285, 1996.

Raven, J. A.: Inorganic carbon acquisition by marine autotrophs, in: Advances in Botanical Research, 27, Callow, J.A., Elsevier, Amsterdam, Netherlands, 85-209, 1997. 
Raven, J. A. and Johnston, A. M.: Mechanisms of inorganic carbon acquisition in marine phytoplankton and their implications for the use of other resources, Limnol. Oceanogr., 36, 1701-1714, 1991.

Raven, J. A., Johnston, A. M., Kübler, J., and Parsons, R.: The influence of natural and experimental high $\mathrm{O}_{2}$ concentrations on $\mathrm{O}_{2}$-evolving photolithotrophs, Biological Reviews, 69, 61-94, 1994.

Romanek, C. S., Grossman, E. L., and Morse, J. W.: Carbon isotopic fractionation in synthetic aragonite and calcite: Effects of temperature and precipitation rate, Geochim. Cosmochim. Acta, 56, 419-430, 1992.

Rosenfeld, J. K.: Nitrogen diagenesis in Long Island Sound sediments, Am. J. Sci., 281, 436-462, 1981.

Rosenthal, Y., Dahan, M., and Shemesh, A.: Southern Ocean contributions to glacial-interglacial changes of atmospheric $p \mathrm{CO}_{2}$ : An assessment of carbon isotope records in diatoms, Paleoceanography, 15, 65-75, 2000.

Schneider-Mor, A., Yam, R., Bianchi, C., Kunz-Pirrung, M., Gersonde, R., and Shemesh, A.: Diatom stable isotopes, sea ice presence and sea surface temperature records of the past $640 \mathrm{ka}$ in the Atlantic sector of the Southern Ocean, Geophys. Res. Lett., 32, L10704, doi:10.1029/2005GL022543, 2005.

Schrader, H. J. and Gersonde, R.: Diatoms and silicoflagellates, in: Micropaleontological counting methods and techniques - an exercise on an eight meters section of the lower Pliocene of Capo Rossello, Sicily, edited by: Zachariasse W. J., Utrecht Micropaleontological Bulletins, 17, Utrecht University, Netherlands, 129176, 1978.

Sharkey, T. D. and Berry, J. A.: Carbon isotope fractionation in algae as influenced by inducible $\mathrm{CO}_{2}$ concentrating mechanisms, in: Inorganic carbon uptake by aquatic photosynthetic organisms, edited by: Lucas, W. J. and Berry, J. A., American Society of Plant Physiologists, Rockville, Maryland, USA, 381-401, 1985.

Singer, A. J. and Shemesh, A.: Climatically linked carbon-isotope variation during the past 430,000 years in Southern Ocean sediments, Paleoceanography, 10, 171-177, 1995.

Sinninghe Damsté, J. S., Rampen, S., Irene, W., Rupstra, C., Abbas, B., Muyzer, G., and Schouten, S.: A diatomaceous origin for long-chain diols and mid-chain hydroxy methyl alkanoates widely occurring in Quaternary marine sediments: Indicators for high-nutrient conditions, Geochim. Cosmochim. Acta, 67, 13391348, 2003.
Struck, U., Pollehne, F., Bauerfeind, E., and v. Bodungen, B.: Sources of nitrogen for the vertical particle flux in the Gotland Sea (Baltic Proper) - results from sediment trap studies, J. Mar. Syst., 45, 91-101, 2004.

Thomas, D. N. and Dieckmann, G. S.: Antarctic sea ice - a habitat for extremophiles, Science, 295, 641-644, 2002.

Thunell, R. C., Varela, R., Llano, M., Collister, J., Muller-Karger, F., and Bohrer, R.: Organic carbon fluxes, degradation, and accumulation in an anoxic basin: Sediment trap results from the Cariaco Basin, Limnol. Oceanogr., 45, 300-308, 2000.

Tortell, P. D., Reinfelder, J. R., and Morel, F. M. M.: Active uptake of bicarbonate by diatoms, Nature, 390, 243-244, 1997.

Tortell, P. D., Rau, G. H., and Morel, F. M. M.: Inorganic carbon acquisition in coastal Pacific phytoplankton communities, Limnol. Oceanogr., 45, 1485-1500, 2000.

Tortell, P. D., Martin, C. L., and Corkum, M. E.: Inorganic carbon uptake and intracellular assimilation by subarctic Pacific phytoplankton assemblages, Limnol. Oceanogr., 51, 2102-2110, 2006.

Trull, T. W. and Armand, L.: Insights into Southern Ocean carbon export from the $\delta^{13} \mathrm{C}$ of particles and dissolved inorganic carbon during the SOIREE iron release experiment, Deep Sea Res. Pt. II, 48, 2655-2680, 2001.

Trull, T. W., Davies, D., and Casciotti, K.: Insights into nutrient assimilation and export in naturally iron-fertilized waters of the Southern Ocean from nitrogen, carbon and oxygen isotopes, Deep Sea Res. Pt. II, 55, 820-840, 2008.

Villinski, J. C., Dunbar, R. B., and Mucciarone, D. A.: Carbon 13/Carbon 12 ratios of sedimentary organic matter from the Ross Sea, Antarctica: A record of phytoplankton bloom dynamics, J. Geophys. Res. C: Oceans, 105, 14163-14172, doi:10.1029/1999JC000309, 2000.

Wakeham, S. G., Peterson, M. L., Hedges, J. I., and Lee, C.: Lipid biomarker fluxes in the Arabian Sea, with a comparison to the equatorial Pacific Ocean, Deep Sea Res. Pt II, 49, 2265-2301, 2002.

Winslow, S. D., Pepich, B. V., Bassett, M. V., Wendelken, S. C., Munch, D.J., and Sinclair, J. L.: Microbial inhibitors for US EPA drinking water methods for the determination of organic compounds, Environ. Sci. Technol., 35, 4103-4110, 2001. 